\title{
أسباب تدني نسبة النجاح للشهادة الثانوية السودانية المساق الفني
}

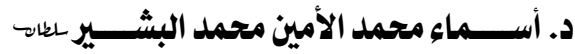

أستاذ مساعد كلية التزبية (مناهج) تكنولوجيا التعليم.

مستخخله البحث:

يهدف هذا البحث إلى دراسـة أسباب تدني نسبـة النجاح في الشهادة السودانية المسـاق الفني وكيفية معالجهة التدني في نسبـة النجاح بعدد من الو سـائل.

اتبعت الباحثة المنهج الوصفي التحليلي وتمثلت أدوات جمـع البيانات و المعلومات الهطلوبة في الاستبـانة و المستندات والوثائق و لهعالجة

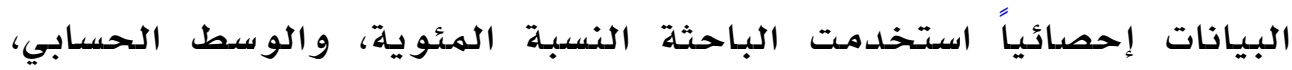
و الانحر اف الهعياري، ومعادلة التنبؤ لاسبيرمان - بروان - ومعادلة بير سون. \section{مجتمع البحث:}

يتكون من موجهي المواد الفنية للهمدارس الفنية بولاية الخرطوم

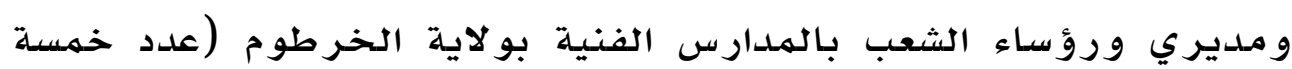
عشر مو جـه فني و أربعة مديري مدارس و و عدد اثنين و ثلاثين رئيس شعبـة). عينة الدراسة: عين قصدية وتمثلت في أربعة مدارس فنية بولاية الخرطوم ويبلـغ عدد الهدارس الفنية بولاية الخرطوم ·1 مدارس فنيـة حيث توجد بالولايـة سبع مدارس صناعيـة وأربع مدارس تجارية بنين وخمس مدارس تجارية بنات و مدرسة نسوية واحدة وتهثلت عين البـحث في الهدارس التاليـة:

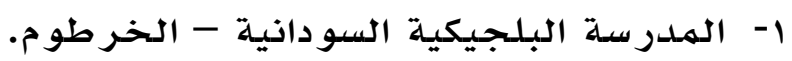
ץ- مدرسة أم درمان الفنية بنين - أم درمـان.

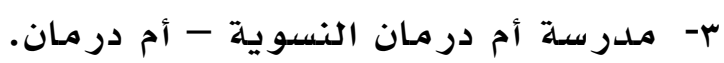
ع- مـدرسة علي السيد التجارية - شرق النيل للبنين. ومن أهم النتائج التي توصلت إليها الباحثة: 
ا- تدذي مستوى الطلاب الهقبولين للتعليهم الفني أثر سلباً على

$$
\text { الهستوى الدر اسي لهمه. }
$$

ץ- مـ أسباب تدني المستوى الدراسي لطلاب التعليهم الفني مححدودية فر ص القبول لهمواصلة تعليمهم العالي.

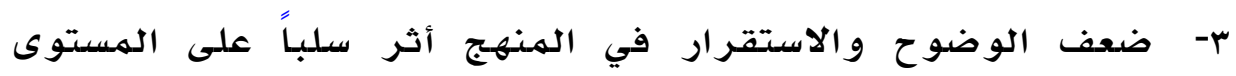

$$
\text { الدراسي لطلاب التعليهم الفني. }
$$

ع- اهتهام الدو لة بالتعليه الأكاديهي أكثر مـن التعليهم الفني أدى إلى

ضعف المستوى الدراسي لطلاب التعليم الفني.

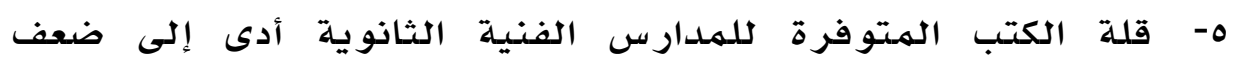

$$
\text { الهستوى الدراسي لطلاب التعليهم الفني. }
$$

ج- الميزانية الضعيفة الهـخصصة للتعليهم الفني أدت إلى عدم توفر

الأجهزة و المعدات و الورش لمدارس التعليهم الفني.

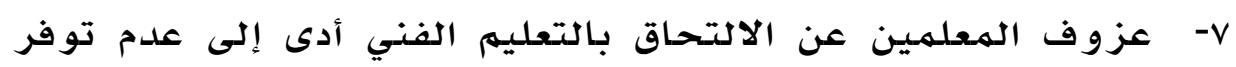
الهعلهم الفني التربوي.

$$
\text { و على ضوء عرض ض أهم النتائج توصي الباحثة بـ: }
$$

ا- إنشاء مدارس نموذجية فنية في كل و لاية من و لايات السودان المختلفة لتحسين نسبـة النجاح في الشهادة السودانية المسـاق الفني.

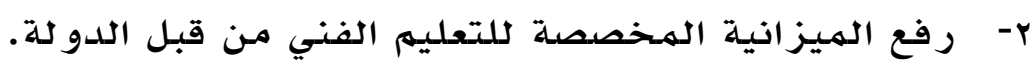

ب- وضع شرووط خلدمهة مسجزية للهعلمين الفنيين وتحسين أوضاعهم. ع- ربط طلاب المدارس الفنيـ بالعهل المنتج وتعويدهم على

الهساهمهة في خدمـة الهـجتهمع من داخل مدارسههم.

$$
\text { ه- وضدوح و استقر ار الهنـاهـج الدراسية. }
$$

ج- توفر الكتب الدراسية و الهعدات الهعمليـة. 


\section{Abstract}

This research is dealing with the low standard percentage in the Sudanese secondary certificate in the technical field and how to raise this standard with several ways.

The researcher used in this research the analysis describable method: and the data's and information's had been collected through documents, approved papers and the questioners, and for statistics data processing she used the percentage, the Arithmetical mean and the standardization deviation of the expectation formula of Spearman - Brown (Person Formula).

\section{The Results were:}

1- The low level of the accepted students in the technical field effect negatively on their academic level.

r- The shortage of chances in high studies for the technical field is one of the reasons of low academic level.

r- Un clearance and changeable studied course helped on this low level.

\&- The government concerning the scientific education more than the technical one.

- $\quad$ The shortage of the published books for the technical field made negative effects.

r- Low budget for the technical field lead to a shortage in equipment, facilities and workshops for the technical schools.

$v$ - Un availability of the technical field teachers.

$\wedge^{-} \quad$ This low level can be treated and corrected by:

1- The Government should increase the concern with technical field. 
r- Build more technical education colleges.

$r$ - Give the technical students more chances in the high-level stdies challenge.

Recommendations:

1- Build perfect technical schools in every state of the different states of Sudan to increase the percentage of success in Sudan Secondary certificate in the technical field.

$r$ - Increase the budget for the technical field.

r- Increase the technical colleges to qualify the teachers.

¿- Put good offers and contracts for the technical field teachers.

- Increase the specialist in this scope $t$ satisfy and cover the technical development needs and the new carriers.

Connect the technical students with their communities and give them the chance to help the society from inside 


\section{الفصل الأول الفول}

الإطار العام للبحث الإڤ

|الإقدمة:

يعتبر التعليهم الفني أساس النهضة لهلأمهم وتطور الهـجتهعات والدول، مهما جعل الاهتهـام بـه متزايدا في الدول التي تقدمت في مـجالات

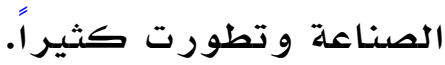

يبدأ الاهتهام بـه من الهمرحلة الثانوية حيث يتهم إنشاء المدارس الفنية و توفير الهعلمين الهؤهلين والكتب و الهعامل والورش و بيئة العمل، لذا كانت الأهميـة العامـة بهذا البحث حتى يتم التر كيز على هذا الجـانب. ونسبة لوجود بعض القصور وتلدني نسبـة النجاح في الشهادة الثانوية الفنية و عزوف الهعلهين وعلم الرضنا بوضعهم و عدم وجود فرص عمل للطلاب و ضعف الهيزانية الهـصصصة للتعليهم الفني جعل هذا الإحساس بالهشكلة وضرورة لفت النظر للاهتهام بالتعليم الفني في الهـرحلة الثانوية، سيتناول الباحث في هذا البحث أهميلة التعليهم الفني، ومفهوم التعليهم الثانوي الفني والأهداف العامـة له وتطوره في وولايـة الخرطوم، وحددت عينـة البحث التي تمثلت في أربعة مدارس فنيـة بولايـة الخرطوم من ضهمن مدر اس الولاية العشرة(حيث توجد سبع مدارس صناعية و كأربع تجارية بين وخمس مدارس تجارية بنات و مدررسلة نسوية و احدة). و يتكون مهتهمع البحث مـن موجهي الهواد الفنية للهمدارس بالو لاية و مديري الهدارس ورؤساء الشعب بالهدارس الفنية بالو لاية وتتبـع الهنهج الوصفي التحليلي وون والأدوات المستخلدمهة لهذه التجربـة الاستبـانة جهـع البيانات و الهعالجات الإحصائية. مشكلة البحث: تتلخص مشكلة البحث في عزوف الطلاب عن التعليهم الفني لعدة أسباب منهها عدم وجود فرص للعمل بعد التخرج مـن الهـدارس الثانوية الفنية و عدم وجود الهعلهـين الهؤهلين والملدربين بالعدد المطلوب وقلة الأجهزة و المعدات و الورش مهما جعل نسبـة نجاح الطلاب في الشهادة الفنيـة السو دانية ضعيف و متدني. 


\section{أهمية البحث:}

أتى البحث بغرض تسليط الضدو على هذه الهشكلة والإسهام في معالجتها بو ضـع الحلول ولفت نظر الهسئو لين في الدو للة للاهتهمام بها. أسئلة البـحث:

ا- هل ضعف الهستوى الدراسي للطلاب الهقبو لين بالمساق الفني أدى إلى تدني نسبـة النجـاح في الشهادة الفنيـة الثانويـة؟ ץ- هل ضعف الهيزانية الهـخصصة للتعليهم الفني لها أثر على تدني نسبـة النجاح في الشهادة الفنيـة الثانويـة س- هل تدذي نسبـة الرضـا الوظيفي لهعلهي المسـاق الفني أدى إلى تدني نسبـة الندجاح؟ ع- هل أدى عدم توفر الكتاب الهدرسي والهعدات والورش إلى تدني نسبـة النجـاح في الشهادة الفنيـة الثانويـئ ه- هل عدم وضوح الرؤيا ووجود فرص العهل بعد التخرج أدى إلى تدني نسبـة النجـاح في الشهادة الفنيـة الثانوية؟ צ- هل كان عدم إتاحة فرص للدراسـات فوق الثانوية للطلاب أدى إلى

إحباط الطلاب وأثر على نسبـة النجاح في الشهادة الفنية الثانوية؟

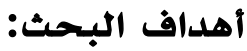

يهدف البحث كلإجابـة على الأسئلة التاليـة:

ا- المستوى الدراسي للطلاب الهقبولين للمدارس الثانوية الفنية و نسبـة مقار نته بـالمدارس الأكاديهيـة. ب- الهيزانية الهخصصة للتعليهم الفني ضعيفة مقارنة بالهيزانية الهو ضو عة كلتعليهم الأكاديهي.

r- نسبـة الرضا الوظيفي للهملـهين و كيفية تحقيقها. ع- كيفية توفير الكتب و الأدوات و الورش بالهمارس الفنيلة الثانويـة. ه- وضدح الرؤيا ووجود فرص العمل للطلاب بعد التخرج والاهتمام بهم .

ج- كيفيـة إتاحة فرص للدراسـة بعد الهـرحلة الثانوية الفنيـة في نفس الهجال الفني لأن أثرها كبير على الطلاب. 
كل هذه الأهداف يتهم تحقيقها من خلال الاستبانة التي سنقوم

$$
\text { فروض بتحلها و البحث: }
$$

/ / يعزى تدني نسبة النجاح في الشهادة السودانية المساق الفني دـ: أ- ضعف المستوى الدراسي للطلاب المقبو لين بالمساق الفني. ب- ضعف الميزانية الهخصصدة للتعليه الفني.

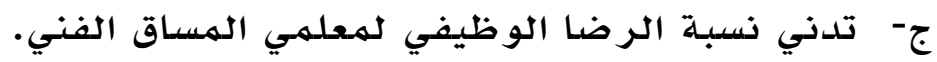
د- عدم توفر الهعلهم التربوي.

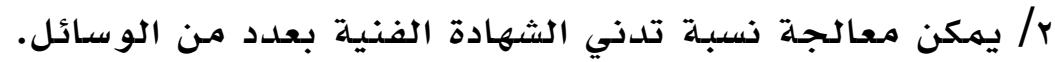
منهج البحث: تستخدم الباحثة الهنهج الوصفي التحليلي. أدوات البحث:

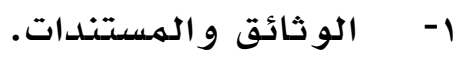
r- r ب الاستبانة.

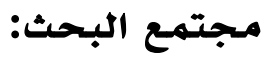

يتكون من مديري ورؤساء الشعب بالمدارس الفنية الثانوية بو لاية

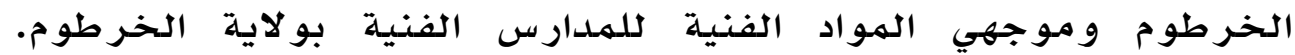

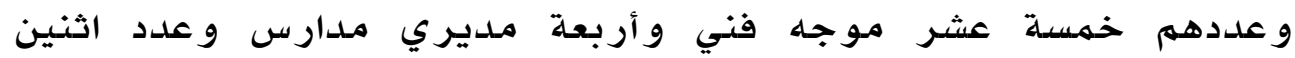
و وثلاثين رئيس شعبـة. مينة البحث: وتنان عينة قصدية وهي مديرو ورؤساء الشعب بالمدارس الفنية الثانوية

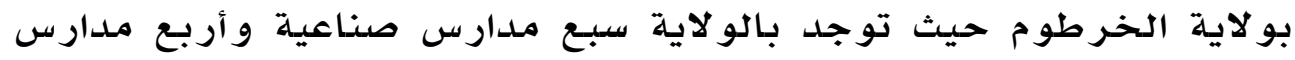
تجارية بنين وخمس مدارس تجارية بنات و مددرسة نسوية و واحدة.

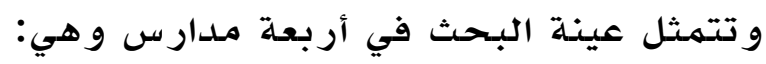

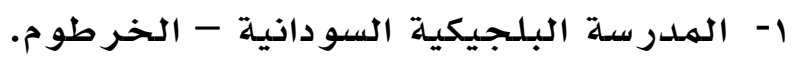

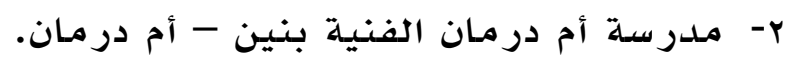

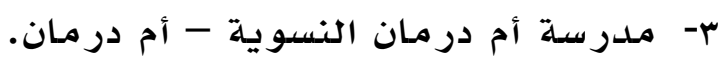
ع- مدرسة علي السيد التجارية - شرق المدان النيل. 
حدود البحث:

/ الحلدود الموضوعية: تستهـدف الدراسـة المـدارس الثانوية الفنية بولاية

الخر طو م.

/ الحدود الزمانية: تتناول الدرماستة نسبة النجاح في القسم الأكاديمي

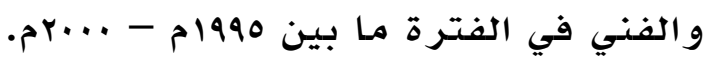

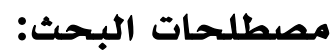
/ / المعنى الاصطلاحي للتعليه:

التعليه: نشاط ذاتي يقوم بـه الهتعلم ليحصل على استجابات ويكون

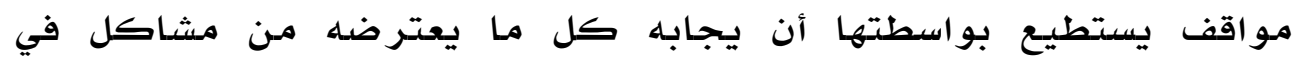
الححياة(1) مواقف)

تعريف آخر: التعله يعرف بأنه تعديل السلوك عن طريق الخبرة و الهر ان وهو تكيف الهتعلهم مـع البيئة(r).

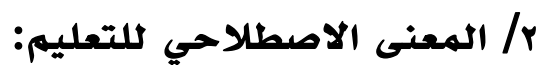
هو تنظيم خبر ات التعلهم (r). r/ المعنى الاصطلاحي للتعليم الفني: تلفيم خيرات التعليم

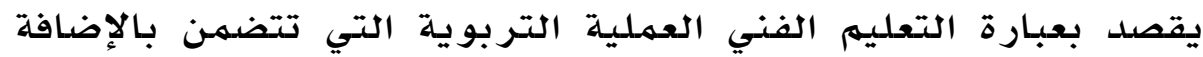

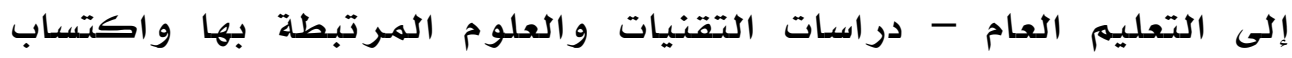

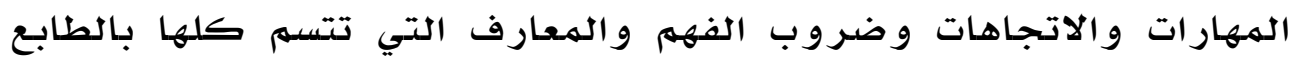

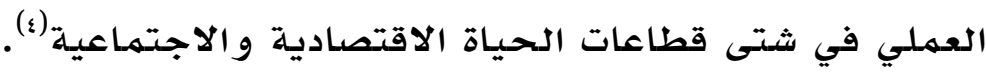

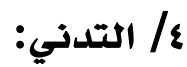

يعني أن نسبة النجاح أقل بكثير بالنسبة للشهادة الثانوية الفنية

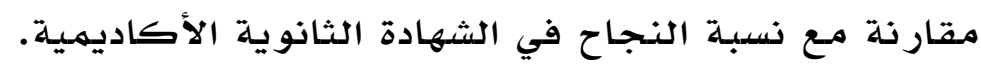
/ الشهادة الثانوية السودانية:

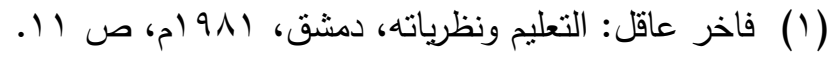

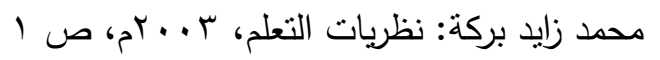

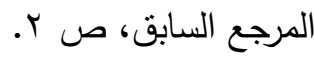

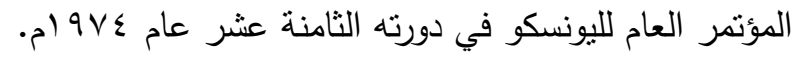


هي الشهادة التي تهنتح بعد إكمال الدراسـة بالهـرحلة الثانوية سواء

كانت أكاديهيـة أو فنيـة. / المساق الفني:

يشهل الهمارس الثانويـة الفنيـة بأنواعها صناعية أو تجـارية أو نسويـة، و يجلس طلابها لامتحان الشهادة الثانوية السودانية.

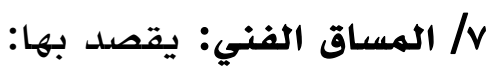

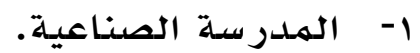
r- الهدر سلة التحسارية.

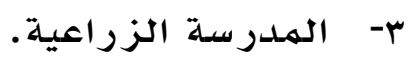
ع- المدارسة النسوية. صعوبات البيحث:

و اجهت الباحثة صعوبات يتعلق بعضها بالإشكاليات التي تواجه إعداد البحوث عموماً بينها يتعلق البعض الآخر بطبيعة الدراسـة نفسها ونذهر منها: / انتشار عينـة البحث: حيث إن عينة البحث تتكون مـن موجهي الهواد الفنية للهدارس الفنية وكذلك مديري ورؤساء الشعب بالمدارس الفنية لهحليات و لايـة الخرطوم مهما جعل عمليـة الاتصال بهم شاقة.

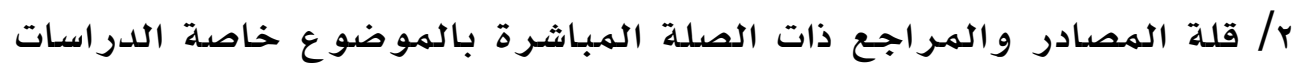
السـابقة الهتعلقة بالهورضوع ملخص الفمل الأول: تناو لت الباحثة في هذا الفصل الإطار العام للبحث ويتمثل في الهقدمهة ثم مشكلة البحث و أهمية و أسباب اختيار مشكلة البحث والهنهج الذي ستتبعـه وأوضحت عينـة البحث والهدارس التي تقصدها ثم حددت الحدود المكانية و الزمانية لبحث ثم أوضحت مصطلحات البحث و صعو باتهـ. 


\section{الأفصل الثاني \\ الإطار النظري للبحث الفي}

تمهيد:

في هذا الفصل تتناول الباحثة الإطار النظري للبحث حيث تتعرض لهفهوم التعليهم الثانوي في السودان والتعليهم الثانوي الفني وتطوره في السودان وولاية الخرطوم كها تناولت الباحث في هذا الفصل الدراسـات السـابقة لأهميتها باعتبـارها مراجع أسـاسية تسـاعد في فهم ووتنظيهم الجـانب النظري للبـحث و تسهم في بناء الأدو ات المستخلدمهة فيه. مفهوم التعليه الثشانوي في السودان:

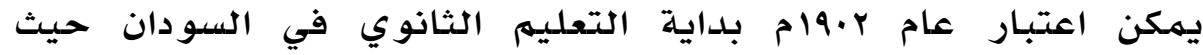
افتتحت كلية غردون التذكارية، وتطور الوضع التعليهي في الكلية ليكون السلهم التعليهمي كهما يلي: ا- أربع سنوات كُتاب "الهـر حلة الابتدائية سـابقاً". ץ- أربع سنوات ابتدائي و الذي سهي فيهـا بعد "الهـر حلة الهتوسطة" . "- و أربع سنوات ثانوي و الذي سهي فيها بعد "الثانوي العالي". وفي العام الدراسي •19V - 19V1ام تقرر أن يكون السلهم التعليهي كهما يلي: ا- المـر حلة الابتدائيـة ست سنوات. r- مـرحلة الثانوي العام ثلاث سنوات.

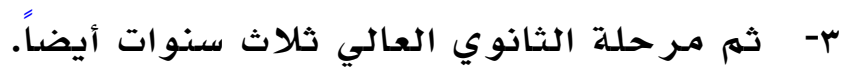
وفي عام س991م طرأ تغيير آخر على السلهم التعليهي حيث تم تغيير اسم الهـرحلة الابتدائية مـرحلة الأساس و أصبـحت ثماني سنوات وتم إلغاء الهـرحلة الهتوسطة وأصبـحت الهـرحلة الثانوية العليا تسهى بالهـرحلة الثانوية و فترة الدراسـة بها ثلاث سنوات و هذا السلهم مستهـر حتى الآن(1). مفهوم التعليم الثانوي الفني: تعريف التعليم الثانوي الفني: 
يقصد بعبارة التعليم الفني العملية التربوية التي تتضهن بالإضافة

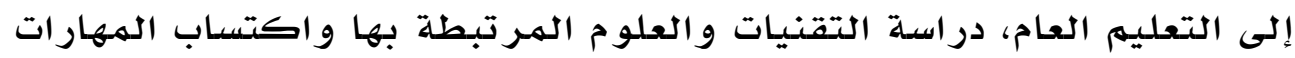

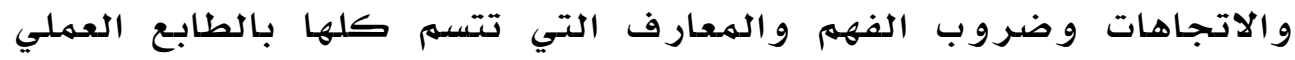
للههنة، و العمل في شتى قطاعات الحياة الاقتصادية و الاجتهماعية(1). تعريف آخر :

التعليهم الفني هو ذلك النوع من التعليهم الذي يمكن الطالب بطريقة

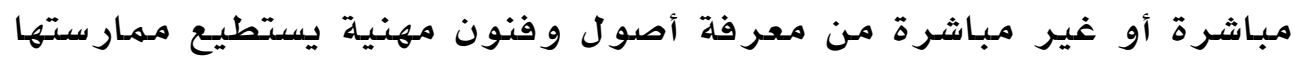

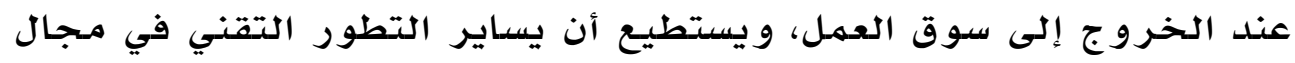

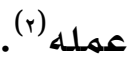
في عام ألهام و وفي إطار الخطة العشرية للتنمية الاقتصادية

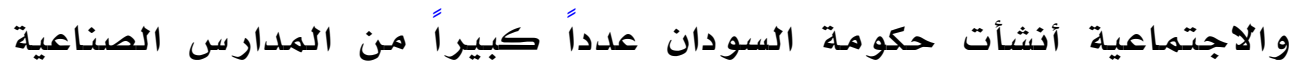

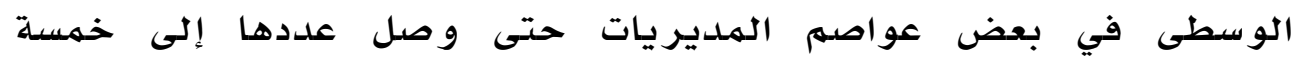

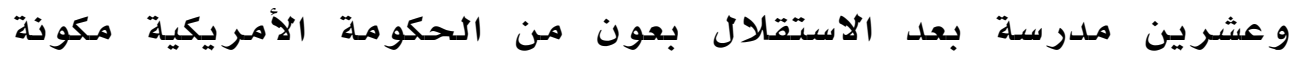

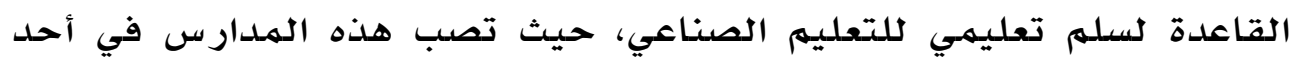
عشر مدرسة مهنية ثانوية يتنافس خريجوها لالالتحاق بالكلية الههنية

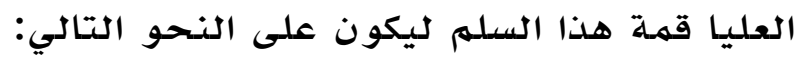

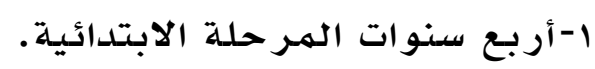

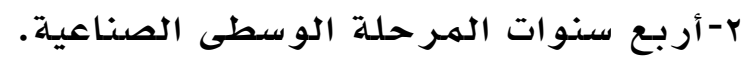

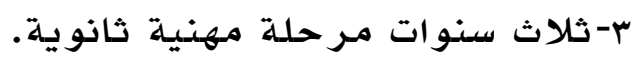

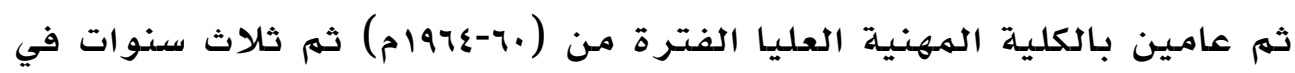

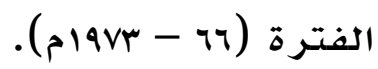

(1) المؤتمر العام لليونسكو ، المرجع السابق، صـه.

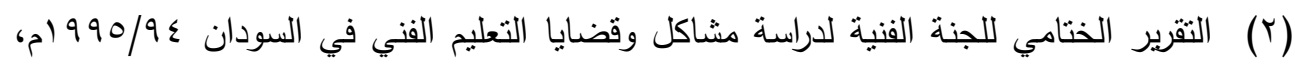
$7 \cdot 1$ 


\section{الأهداف العامة كلتعليم الفني في المرحلة الثانوية(1):}

ا- إعداد الطلاب روحياً وجسلياً و عقلياً و خلقياً و اجتماعياً وتزياً وويدهم الهم بالقدر الهناسب من الثقافات والههارات التي من شأنها الوصول بهم إلى مستويات للعهل في ميادين الإنتاج الصناعي والزراعي و التجاري و غير ها مـن الخدمـات الأخرى.

ץ- ربط خطط تطوير التعليه الفني بخطط التنهيـة الاقتصسادية. ب- فتح مجال للمبرزين من الخريجين لهواصلة دراستهم في الجـامعات و الهعاهد العليا.

ع- إعداد جيل من الهواطنين يقدر العهل ويهـجده و يمـارسـه عن رغبـة و اعتز از مـن أجل حياة أفضل ويؤمسن بأن العمل حق وشرف وو اجب. ه- تعبئة الهموارد وتفجير الطاقات لزيادة الإنتاج ورفع مستوى الهعيشة وتنهية الاقتصساد الوطني. צ- تشجيع الطلاب على التعليهم الذاتي في مـجال تخصصهم مـها يسـاعد على الاستتهر ار في التعليهم مدى الحياة. V- تحويل الفرد من متلق سلبي ومستهلك للعلوم والتكنولوجيا الحديثة إلى مبتكر يتعامل مـع التقنيـات بوعي و إدراك. تطور التعليم الفني في السودان: في الربع الثالث مـن القرن العشرين حيث قامت ثورات وطنيـة في البـلاد العربية وفي كثير مـن البلاد النامية حولت الكثير من الهفاهيم القديهـة وبرزت بذور الإيهان بالتكنو لوجيا والاعتر اف بضرور تها لتهكن

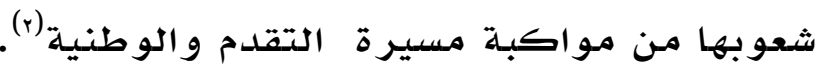
رغم أن التعليهم الفني قد بدأ في السودان في النصف الثاني مـ القرن

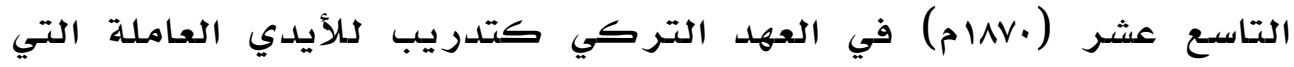
احتاجها العهل في شتى مجالات الإنتاج كعمالة ماهرة وشبـه مـاهرة (حرفي) إلا أنه بدأ تعليهاً نظامياً في أوائل القرن العشرين في كلية

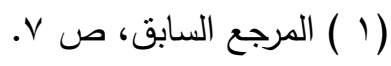

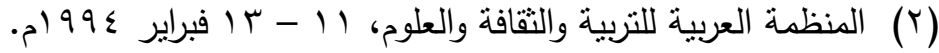


غردون التذكارية، حيث أعدت مناهـج لإعداد الفنيين و العمال الههرة في الهندسة الهمدنية والهسياحة والمهحاسبة والأعمال الكتابية في السنتين الأخيرتين من سنوات الدراسـة التي كانت أربع سنوات بعد المدررسة الو سطى.

وفي عام 19\&1م في إطار الخطة العشرية للتتهمية الاقتصادية و الاجتهـاعية أنشأت حكومـة السـودان عدداً من الهدارس الصناعيـة الوسطى في بعض عواصلم المديريات حتى و صل عددها إلى خهس و عشرين مدررسة

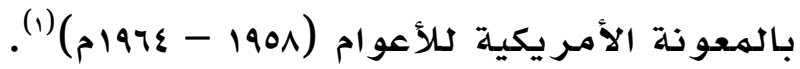

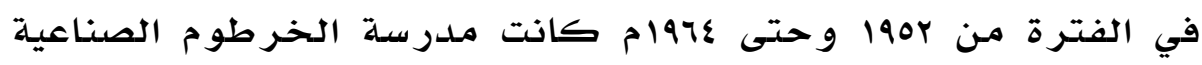
الثانويـة العليا (أربع سنوات) هي المدرسة الصناعية الثانويـة الأولى التي ير تادها الناجحون من الهدارس الصناعية، و منهها إلى الأقسسام العليا بالهعهد

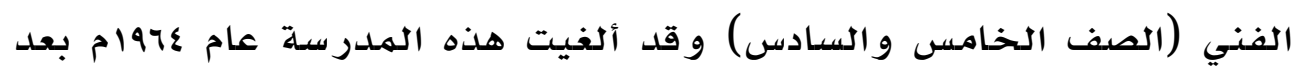
اكتهمال سلم الكلية الههنية، وكانت إلى جانب تغذيتها للأقسام العليا تعدل الكوادر الوسيطة في الميكانيكا والكهر بـاء والسيـارات و الهندسـة الهعمارية والر سمر الفني.

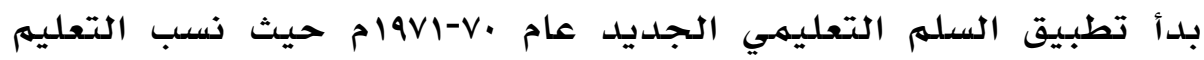
الفني إلى مـرحلة التعليم العام. و بعد تنويعه بإضـافة الهسـاقات (التجـاري الزراعي - النسوي) إليه نسب إلى الهر حلة الثانوية الفنية وحددت فتر ته الدراسيـة بأربع سنوات وذلك حتى يتهـن خريجه أن يكون صنواً لخريج المدرسة الأكاديمية في الهواد الأسـاسية (اللغة العربية - اللغة الإنجليزية

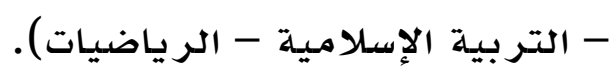
و من ثم الهواد الثقافيـة وفق الهسـاق الصناعي (فيزياء - جغرافيا) و المسـاق التجاري (تاريخ) و المساق الزراعي و النسوي (أحياء - كيمـياء). و حددت أهدافه بإعداد الكوادر الوسيطة (المساق الفني) لسوق العهل العل الهيل مـع إتاحة الفرصدة للنابغين من طلابه للمنافسة للمعاهد العليا والجامعات.

(1) التقرير الختامي للجنة الفنية لدراسة مشاكل وقضايا التعليم الفني في السودان ع990/9 ام. 
وفي عام •9-1991م تم تخفيض سنين الدراسلة في المدارس الفنية الثانوية

إلى ثلاثة سنوات مثيلاً لصنوه الأكاديهي وهو النظام السـاري(1).

و في الفترة من (1917 - 1991م) زاد عدد مدارس التعليهم الفني بنسبـة

عالية لهم تبلغها من قبل، ولكن هذه الزيادة كانت فقط في تخصيص بعض الهدارس بعد تجفيف الهـرحلة الهتوسطة دون الاعتبار الكافي لتكملة الهباني و التأهيل بالمعدات و استقطاب المعلمين (فنيين و أكاديهيين) وقدين بلغت مؤسسات التعليهم الفني ما يلي:

ا- مدراس صناعية ثلاثة و أربعين مدرسة تعهل منها الآن تسعة

$$
\text { و ثلاثون مدر سـة . }
$$

ץ- مـارس زراعية إحدى عشر مدرسة تعهل منهها الآن سـت مدارس. ب- مدراس تجارية خمسة وستين مدرسة تعهل منها الآن و احل و خهسين.

ع- مدارس نسوية إحدى عشر مدرسة تعمل منها الآن خمس مدارس.

تطور التعليم الفني في ولاية الخرطوم: تعتبر مدرسة أم درمان الصناعية أول مدرسة فنية بالسودان وأول مدرسلة بولاية الخرطوم حيث تم تأسيسها عام 9roام و تلدرجت مـ مدرسة الحجر إلى الملدرسـة الوسطى الصناعية ثم الثانوية الصناعية في الفترة

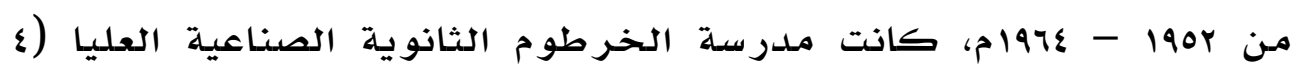

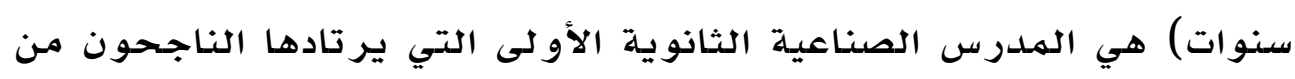

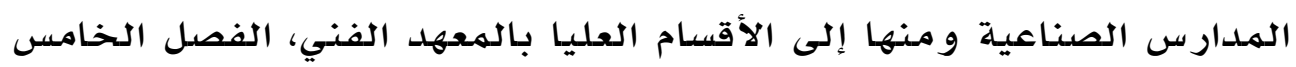
و السـادس) ( قبل السلهم التعليهي 19V/79/م كان يقصد بالتعليهم الفني التعليهم

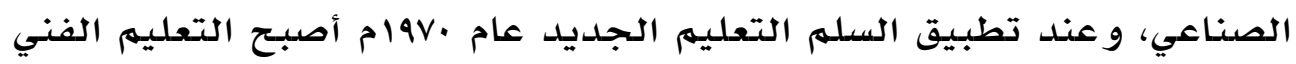
متتوع المساقات بإضـافة المساق التجاري و الزراعي و النسوي. وبعد تطبيق

(1) التقرير الختامي للجنة الفنية لدراسة مشاكل وقضايا التعليم الفني في السودان ع9 /99 ام. 


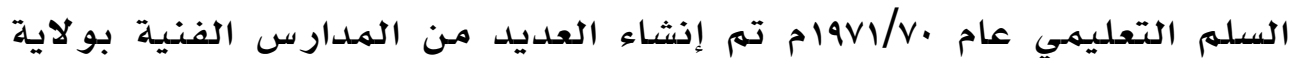

$$
\text { الخر طوم (1) (1) }
$$

\section{المدارس المسناعية:}

تم إنشاء الهمدارس الآتية:

أ- الملدرسة البلجيكية السودانيـة والتي قامت على نفقة الهملكة

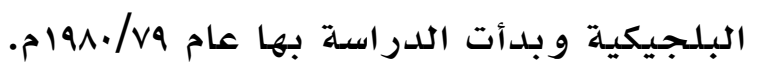

ب- مدررسـة علي السيد الصناعيـة قامت على نفقة الخير علي السيد أو ائل الثهانينات.

ج- مدررسـة الحلفايا الفنية: أنثأتها الوزارة الاتحادية وقامت بتكملتها الوزارة الو لائيـة.

د- ملدرسة جبل أولياء ته افتتاحها أو ائل التسعينات.

ه- ملدرسة أبو سعد تهم افتتاحها أواخر التسعينات.

المدارس التجارية:

تم إنشاء الهدارس التجارية التاليـة:

ا- الخخرطوم التجارية بنين.

ץ- أم درمان التجارية بنين.

r- الحلفايا التجارية بنين.

ع- علي السيد التجارية بنين.

ه- أم درمان التجارية بنات.

7- الخر طوم التجارية بنات.

- - الحمير اء التجارية بنات.

- - الخير موسى التجـاريـة بنات.

ه- المدارس النسوية: ثم قيام الملدرسـة النسوية بأم درمـان والتي

تعتبر أول مدررسة نسوية بالو لايـة و بالسدودان(r).

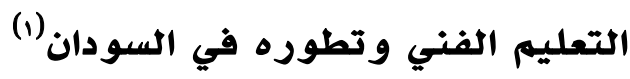

(1) التقرير الختامي للجنة الفنية لمعالجة مشاكل وقضايا التعليم بالسودان ع99 ام.

(r) التقرير الختامي للجنة الفنبة لمعالجة مشاكل وقضايا التعليم بالسودان ع9 9 ام. 


\begin{tabular}{|c|c|}
\hline & 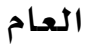 \\
\hline دخول الأتر الك السـودان & $|\wedge Y|$ \\
\hline تعليهم الكتاب (ابتدائية) في عهد الأتر الك & $1 \wedge \varepsilon 7$ \\
\hline بدايـة التعليهم الحررفي في عهد الأتر الك (ورش) & $1 \wedge \mathrm{V} \cdot$ \\
\hline بداية التعليهم العام في السودان (كلية غردون التذكارية) & $19 \cdot r$ \\
\hline مدرس سلة الحجر بأم درمان & 1970 \\
\hline بلدء مشرووع التوسـع في التعليهم الفنـي & $19 £ 7$ \\
\hline أو ل مدرراس صناعية و سطى (أم درمـان/ الأبيض) & $19 £ 9$ \\
\hline مـدذي الصنـاعيـة الوسطى & 190. \\
\hline فتح الأقسام العاليـة بالمعهد الفني وبـاية المعهد العالي & 190. \\
\hline عطبرة الصنـاعيـة الوسطى & 1901 \\
\hline أول مدررسة صناعية ثانوية بالهعهد الفني (K.T.S) & $190 Y$ \\
\hline بداية المدار س المهنية الثانوية (ثلاث سنوات) & $190 \mathrm{~V}$ \\
\hline فتح الكلية المهنيـة العليا & 197. \\
\hline إلغاء الهـلدرسـة الصنـاعيلة الوسطى & $197 \varepsilon$ \\
\hline إلغاء المدررسـة الصناعيـة الثانوية العليا (K.T.S) & 1970 \\
\hline السلهم التعليهي الجديد و إدخال الشهادة السـودانية الفنيـة & $19 \times 1$ \\
\hline بداية الهعاهد الحر فية (ودي - واو - نيالا - أم درمـان) & I9VY \\
\hline تعديل الفترة الدرراسيـة بالمدارس الثانوية إلى ثلاث سنوات & 1911 \\
\hline تعديل الفترة الدراسيـة بـالهدارس الثانوية إلى أربـع سنـوات & 1914 \\
\hline أول امتححان شهادة بنظام الثلاث سنوات & 1994 \\
\hline
\end{tabular}

الدراسات السابقة:

(1) التقرير الختامي للجنة الفنية لدراسة مشاكل وقضايا النعليم الفني في السودان ع990/9 ام أرشيف التعليم الفني بالوزارة. 
في هذا الجزء تتناول الباحثة موضوع الدراسات السابقة لأهميتها في مجال البحوث للاستفادة منها في تنظيهم الجانب النظري للدراسلة وبناء

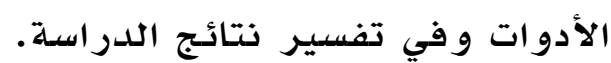

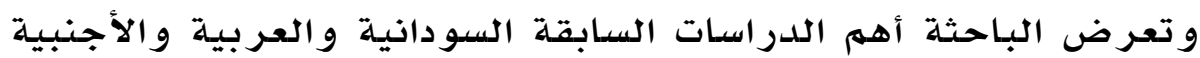
التي تحصلت عليها و لها علاقة بالتعليم الفني.

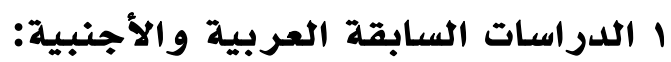

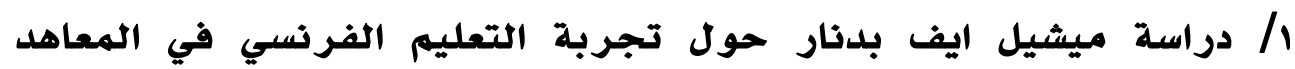

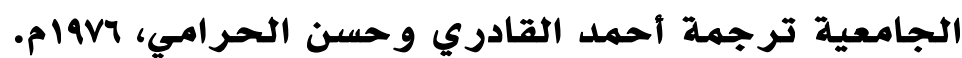

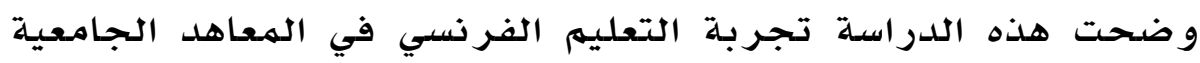

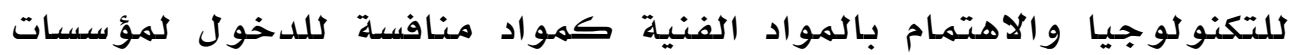

\section{التعليم العالي. \\ أهم النتائج التي توصل إلئيها.}

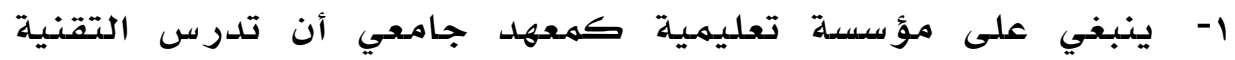

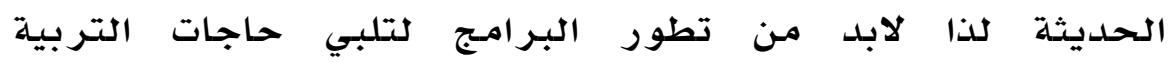
الهستهمرة.

ץ- يعتبر الباحث أن العقبة الأولى تكمن في ازدواجية طرق الانتقاء للنطلاب.

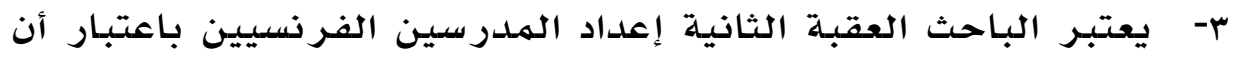

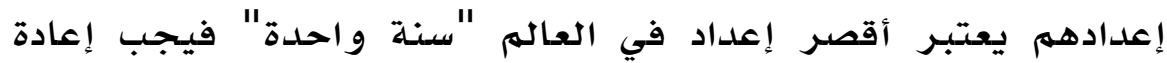
النظر فيه.

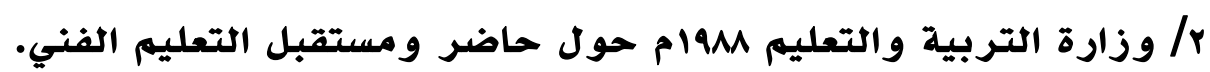

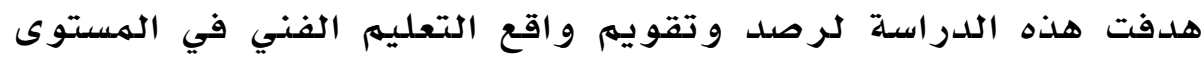

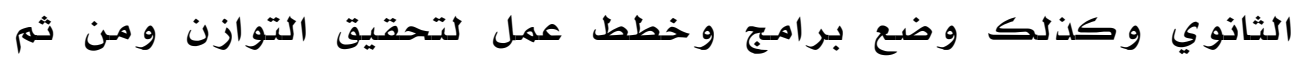

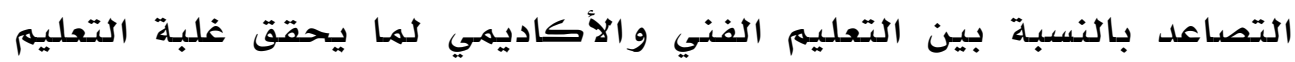

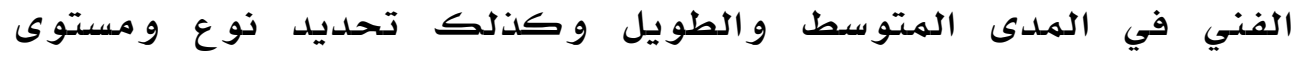

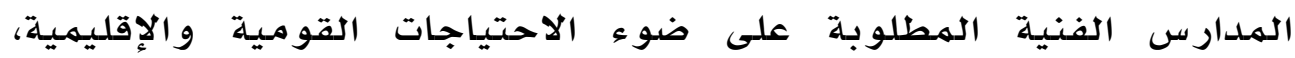

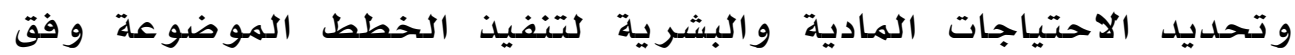
$7) \leqslant$ أسبقيات محددة. 
من أهمر النتائج التي توصلت إليها الدراسـة:

ا- مـراجعة البرامـج التعليهية في شقيه الأكاديهي و الفني بغرض تأهيل و تعميق قاعدة "العلدم من أجل العمل ".

ץ- إدخال مـزيد مـن التخصصدات التي تلبي احتياجـات التطور المستهمر و ظهور الههن الجحديدة.

ب- و ضـع شروط خلدمة مسجزية للهعلمين الفنيين حتى يتمر استقطاب و استهـر ار الهعلم الكفء للعهل في هذا الهـجال. r/ دراسة فؤاد بسيوني متولى 9191ام حول التعليم الفني، تاريخه، تشريعاته، اصطلاحماته، مستقبله.

هدفت الدراسة إلى تعريف التعليهم الفني وكذلك اصطلاحاته وتشريعاته، و كذلك هدفت الدراسـة لتوثيق تاريخ التعليهم الفني مند بداية القرن التاسـع عشر وحتى نهاية القرن العشرين بجمهوريـة مصر العربية. أهم النتائج التي توهلت إليها الدراسة:

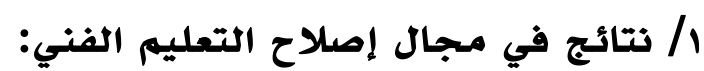
أ- عدم توفر البيانات الكافية عن الاحتياجات الحالية والهستقبلية من العهالة الفنية و الكوادر لمستوياتها وتخصصاتها الهختلفة بها لا يسهم بالتخطيط السليهم. ب- قلة الهيزانيات الهـخصدة للتعليهم الفني بالرغم مـن اهتمام الدو لة بهذا النوع من التعليهم. ج- عدم التأهيل للكليات الجامعية إلا مـن النادر القليل. ع/ دراسة التقرير الختامي للجنة الفنية للراسة مشاكل وقضايا التعليم الفني في السودان - أرشيف التعليم الفني 1998 - 1990م. هدفت هذه الدراسة لمعرفة مشاكل وقضايا التعليهم الفني في السو دان.

الهنهج الهستخدم في هذه الدراسـة هو الهنهج الوصفي والأدوات التي استخدمتها هي التقارير والوثائق وتم استخدام النسـب الهئوية في المعالجـة الإحصائيـة. و توصلت الدراسـة إلى نتائج أههـها: 
ا- رفع التعليهم الفني ليوازي التعليهم الأكاديهـي باعتباره التعليهم الذي يعد الكوادر المدربة التي تأخذ بأسباب التطور وتدفع عجلة التتهية في الهـحتهـع.

ץ- الاهتهمام بالتعليهم الفني وتطوره وزيادة نسبـ وتحديد مساره وو ضع هياكل و أطر إدارية و فنيـة فاعلة.

ب- تكوين جهاز جامه يجمهع كل الههتمين بالتعليهم الفني لوضع السياسـات التعليهيـة واحتياجات التنهيـة والتنسيق بين مؤسسات التعليهم الفني للاستغلال الأمثل للموارد البشرية و المادية الهتاحة

$$
\text { في كل المواقع. }
$$

ه/ دراسة محمد حسن شلبي 1991م - ورقة لحلقة المدارسة حول تدني نتائج الشهادة الفنية التي عقدت بقاعة الشهيد بالمقرن. هدفت هذه الدراسـة لهعرفة أسباب تدني الشهادة الفنيـة ووكذلك تم في هذه الدراسة مقارنة للبيئة المدرسية بالهدارس الأكاديهية و النهموذجية والفنية الحكومية، وقد أوضحت هذه الهقارنة أن الهدارس النهموذجية احتلت المواقع الهتقدمـة في نتائج امتحانات في الأعوام الأخيرة بينهما تر بعت المهدارس الفنيـة في ذيل القائمهة. اتبعت الدراسـة الهنهج الوصفي التحليلي وكانت أدوات جهـع البيانات هي التقارير والوثائق كما استخدمت الدراسـة بعض الإحصاءات تمثلت في النسبـة المئو يـة.

و مـن أهم النتائج التي توصلت إليها هذه الدراسلة أن البيئة الهدرسية لها تأثيرها على تحصيل الطلاب ونتائجهم ويقصد بالبيئة الهدرسية كل الظروف و العوامل الهـحيطة بالملدرسة وتشهل:

$$
\begin{aligned}
& \text { ا- الهمباني المدررسية. } \\
& \text { ץ- المعدات و الآليات. } \\
& \text { r- الهعلمون. } \\
& \text { ع- الطلاب. }
\end{aligned}
$$

- - الهناهـج الهدر سيـة و الكتب.

$$
\text { ب- الإدارة }
$$




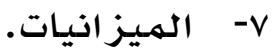

7/ دراسة محمد محمد سكران (r..l) التعليم والتقلم التكنولوجي

والهناعي التجربة اليابانية.

هدفت هذه الدراسـة إلى التعرف على تجربـة اليابان في التعليهم الفني، فقد أوضحت هذه الدراسـة أن ما تحقق في اليابان من تقدم وتفوق اقتصادي ووصناعي بعد الحرب العالهية الثانية إنها كان بفضل الهـخزون البشري الذي ته تكوينه عن طريق تلك الاستثمارات الكبيرة في التعليها

الفندي.

من أهم نتائج الدراسة:

ا- تعتبر التجربة اليابانية في مجهال التعليهم الفني والتقدم التكنولوجي و الصناعي في الهـجتهـع الياباني من التجارب الرائدة التي يهكن الإفادة منها في بلدان العاله.

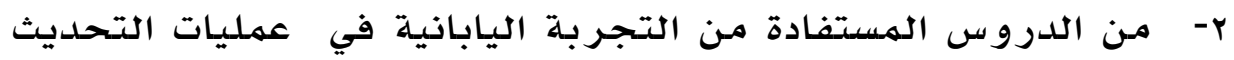
و التصنيـع من توافر الزعامـات الواعية الهتفتحلة القادرة على قيادة الأمهم العر يقة. س- أيضاً من الدروس المستفادة مـن التجربـة اليابانيـة تبنـي الأهداف الهـرحليـة و السياسـات الهر نة كلتكيف مـ الهو اقف الجديدة. ع- مـن الدروس أيضاً النظر إلى عمليات تصنيع الهـجتهـع على أنها للنهوض ضه و الوسيلة الأساسية للقضاء على ما يعانيـه مـن تخلف

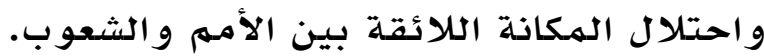
ه- أيضاً من الدروس النظر إلى التعليهم على أذه الوسيلة الهضهونة لتحديث الهـتهمع وتنهيته و الهضي بخطى واسعة نحو الرقي

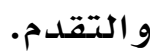

צ- النظر إلى الاستثمار في التعليهم على أنه أفضل أنواع الاستثمار لأنه يتعلق بتشكيل وإعداد الإنسان القادر على القيام بعمليات التحديث و التصنيع و التقدم. كل هذه الدراسات تناو لت الهعالجات التي يهكن أن تؤدي إلى تطوير التعليهم الفني وهنالك تجارب ذكرت للاستفادة 
منها. و الباحثة حصرت دراستها في السودان وخاصدة و لاية الخر طوم وحلددت معوقات و أسباب قد لا تكون موجودة لدى أصحاب الدراسات السابقة في بلدانهم ولكن لدينا في السودان تحتاج لمعالجات ووقوفات لكات لابد

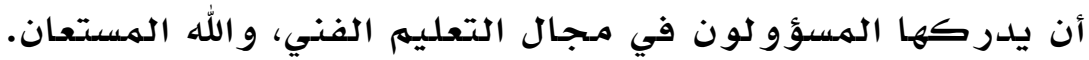
مدى الاستفادة من الدراسات السابقة:

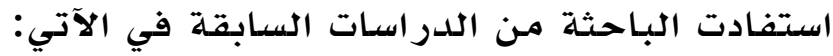
ا- - ساهمت في فهم مشكلة البحث.

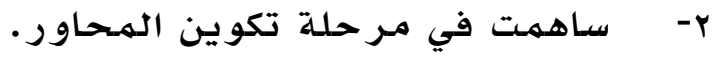
r- ساعدت في تحديد منهج البحث. ع- ساهمت في بناء و صياغة العبار ات. ه- سماعدت في تفسير النتائج.

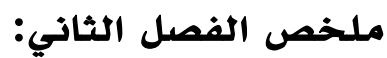

تناولت الباحثة في هذا الفصل الإطار النظري للبحث الذي تناولت فيه مفهوم التعليه الثانوي و مفهوم التعليه الفني، ثم تطور التعليه الفني

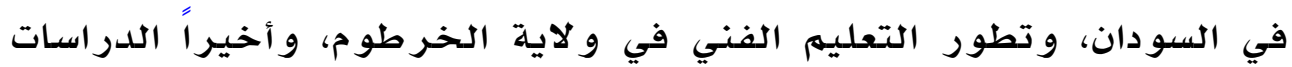

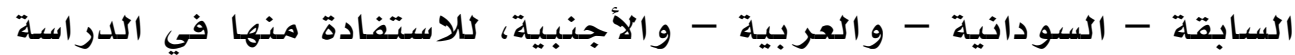

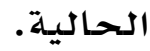




\section{الفصل الثالث \\ منهج البحث وإجراءاته الثفاء}

تمهيد:

في هذا الفصل تناولت الباحثة إجر اءات الدراسلة الهيدانية، و التي عن طريقها تتوفر البيانات و المعلومـات التي تسهم في تحقيق الأهداف الهـرجوة مـن هذا البحث والتحقق من صححة فروضه وتقود إلى النتائج المطلدوبة.

و تتمثل هذه الإجراءات في تحديد منهج البحث الهستخدم وتحديد وو صف مجتهمع البحث والعينة و أدوات البحث الهقننة ثباتاً و وصدقاً و طريقة الهعالجة الإحصائية للبيانات ووكيفية جمـع المعلومات. منهج الدراسة:

في هذا البحث تتبـع البـاحثة الهنهج الوصفي التحليلي، أي البحث عن أوصاف دقيقة كلأنشطة والعمليات، ثم تقنين أساليب جمـع المعلومـات، ثم و صف النتائج و تحليلها و تفسيرها في عبارات واضحة على ضوء الفروض و ذلك باستخدام للر موز الكيفية و الكهية.

مجتمع البحث:

يتكون من موجهي المواد الفنية للهمارس الفنية بولاية الخرطوم و مديري ورؤساء الشعب بالمدارس الفنية بولاية الخر طوم (عدد خمسة عشر مـوجه فني و أربعة مدير مدررسة و اثنين و ثلاثين رؤيس ثعبـة). عينة البحث:

عينـة قصدية وتمثلت في أربعة مدارس فنيـة بولايـة الخرطوم ويبلغ عدد المدارس الفنية بولاية الخرطوم عشر مدارس فنية حيث توجد بالو لاية سبـع مدارس صناعيلة وأربع مدارس تجارية بنين وخمس مدارس تجارية بنات و مدرسة نسوية واحدة وتمثلت عينة البحث في الهدارس

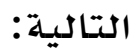

$$
\begin{aligned}
& \text { 1- المهدرسة البلسجيكية السودانية - الخر طوم. } \\
& \text { ץ- مدرسة أم درمان الفنية بنين - أم درمان. } \\
& \text { r- مدرسة أم درمان النسوية - أم درمان. }
\end{aligned}
$$


ع- مـدرسة علي السيد التجارية - شرق النيل للبنين.

r-ع-1 و صف عينة البحث:

/ الجنس: الجلوول (r-1) يوضع توزيع أفراد العينة

حسب الجنس والنسبة المئوية

\begin{tabular}{|c|c|c|c|c|c|}
\hline المجموع & $\%$ & اثڤى & $\%$ & ذكر & الوظيفة \\
\hline 10 & $\%$ & $r$ & $\%$. & ir & موجه فني \\
\hline$\varepsilon$ & $\%$ & 1 & $\%$ Vo & $r$ & مدير مدرسة \\
\hline rr & $\%$ Y TO & $\Lambda$ & $\%$ Vo & $r \varepsilon$ & رئيس شعبة \\
\hline 01 & $\%$ Tr.O & ir & $\%$ V & 79 & المجموع \\
\hline
\end{tabular}

توزيع أفراد العينة حسب العمر

\begin{tabular}{|c|c|c|c|c|c|c|}
\hline المجموع & 7.07 & $00 \_01$ & 0.57 & $\varepsilon 0 \_\Sigma 1$ & $\varepsilon \cdot . M$ & الوظيفل \\
\hline 10 & 0 & 7 & $r$ & 1 & - & موجه فني \\
\hline$\varepsilon$ & - & $r$ & - & - & 1 & مدير مدرسة \\
\hline rr & $r$ & $r$ & $r$ & 11 & ir & رئيس شعبة \\
\hline 01 & $v$ & ir & 7 & ir & $1 \varepsilon$ & المجموع \\
\hline
\end{tabular}

توزيع أفراد العينة حسب الوظيفة

\begin{tabular}{|c|c|c|}
\hline$\%$ & العدد & الوظيفة \\
\hline$\% r$. & 10 & موجه فني \\
\hline$\% \wedge$ & $\varepsilon$ & مدير مدرسة \\
\hline$\%$ \%r & rr & رئيس شعبة \\
\hline$\% 1 \ldots$ & 01 & المجحموع \\
\hline
\end{tabular}

جدو J (q- (q)

توزيع أفراد العينة حسب الدرجة الوظيفية

\begin{tabular}{|c|c|c|c|c|c|c|c|c|c|c|c|c|c|}
\hline المجمموع & $\%$ & $r$ & $\%$ & $r$ & $\%$ & $\varepsilon$ & $\%$ & 0 & $\%$ & v & $\%$ & $\Lambda$ & الوظيفة \\
\hline 10 & $\%$ \%q.0 & 7 & $\%$ \% & 7 & $\% 1 \varepsilon$ & $r$ & $\% \vee$ & 1 & - & - & - & - & فوجني \\
\hline$\varepsilon$ & $\%$ マ৩ & $r$ & - & - & - & - & $\%$ ro & 1 & - & - & - & - & مدرسير \\
\hline rr & $\% 1.0$ & $r$ & $\%$ \% & V & $\% 10.0$ & 0 & $\% 10.0$ & 0 & $\% 7.0$ & $r$ & $\%$ r & 11 & شعبيس \\
\hline
\end{tabular}

$7 r$. 


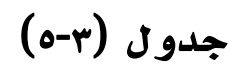

\section{توزيع أفراد العينة حسب سنوات الخبرة}

\begin{tabular}{|c|c|c|c|c|}
\hline المجموع & أكثر من·r & 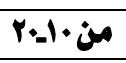 & أتل من · اسنوات & سنوات الخبرة \\
\hline 10 & $1 \varepsilon$ & 1 & - & موجه فني \\
\hline$\varepsilon$ & $\varepsilon$ & - & - & مدير مدرسة \\
\hline rr & ir & 1. & 1. & رئيس شعبة \\
\hline 01 & $r$. & 11 & 1. & المجموع \\
\hline
\end{tabular}

من الجدول يتضح أن خبرة معظم أفر اد العينة أكثر من ·r سنـة. جدول (r-r)

\section{توزيع أفراد العينة حسب المؤهلات العلمية}

\begin{tabular}{|c|c|c|c|}
\hline المجموع & فوق الجامعي & جامعي & المزهل \\
\hline 10 & $\varepsilon$ & 11 & موجه فني \\
\hline$\varepsilon$ & $r$ & 1 & مدير مدرسة \\
\hline rr & $r$ & $r q$ & رئيس شعبة \\
\hline 01 & 1. & \&1 & المجمموع \\
\hline
\end{tabular}

من الجدول يتضح أن معظم أفراد العينة يحملون المؤهل الجامعي وبقية أفر اد العينـة يحملون مؤهلات فوق الجدات الجامعية.

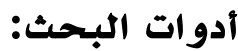

تعتبر عملية جمـع الهعلومات والبيانات الهميدانية مـن أهم الخطوات المنهجية للبحث وبقدر ما تكون البيانات دقيقة وعلى درجة عالية من المـوضوعية تكون موضو عية النتائج ودقتها حيث يوظف الهئ الباحثون العديد

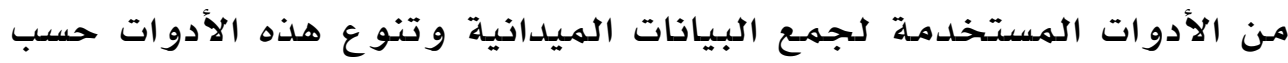

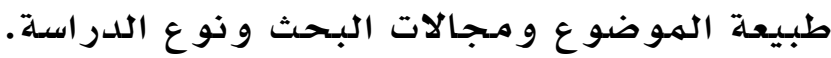

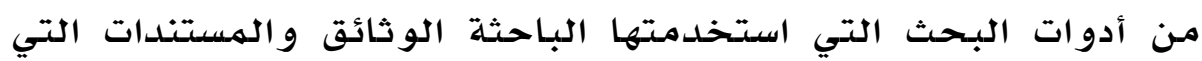
لها علاقة بقضايا ومشاكل التعليم الفني. كذلك استخدمت الباحثة الاستبانة التي وجهتها إلى موجهي المهواد الفنية للمدارس الفنيلة بولاية الخر طوم، و مديري ورؤساء الشعب بالمدارس الفنية بو لاية الخر طوم.

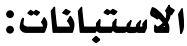
تعتبر الاستبانة مـ أهم الأدوات التي يستخدمها غالبية الباحثين 
و الدارسين كوسيلة لجمـع البيانات وذلك لعدة أسباب أهمها سهولة التعامل معها قياسـاً بالأدوات الأخرى التي تحتاج إلى وقت وجهد كبير ين كالمقابـلات مثلاً (1).

إلا أن إعدادها ليس سهالا" إذها هي في الحقيقة تحتاج إلى الشيء الكثير مـن جهد الباحث ووقته وذلك لأن دقة نتائج البـحث وموضو عيتها

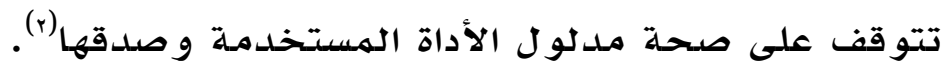
اعتمدلت الباحثة في تصميهم الاستبانة على ما توفر لديها من معلومات وو ثائق ودراسـات سابقة في مسجال الدراسـة حيث تم تحديد مهحاور الدراسـة في مسجال الدراسـة حيث تم تحديد مححاور الدراسـة ثم تمت صياغة عبارات الاستبانة بالطريقة التي تعطي أكبر قدر من الهعلومات. و لقد روعي في تصميهم الاستبانة شكلها من حيث التنسيق، و صسياغة العبارات من حيث اللغـة. اشتملت الاستبـانة على خطاب تقديهم يتناول الهدف مـن الدراسـة ومدى أههيتها و تشجيع المشاركين على التعاون و الاستجابـ، كها اشتهلت الاستبـانة على جزأين رئيسيين. الجزء الأول: يحتوي على معلومات وبيانات أولية عامه عن المستجيب

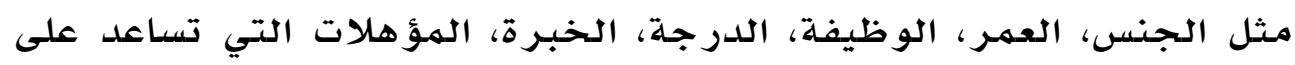
و صف وتصنيف العينة كها تساعد على فهم وتفسير استجاباتهم لعبارات الاستبانة.

الجزء الثهاني: يتكون مـن محاور وضعت بحيث تلائم محاور كل استبانة ودور كل مهجمـع من الهجتهعات الهـختارة وبهـا يتفق مـ الهعلومات التي ير اد الحصول عليها، كها اشتهمل كل مهحور على عدد من العبارات توضح الجوانب المتعلقة بفروض البحث، وهي نوع من العبارات المغلقة ذات التدرج الثلاثي حيث تكون الإجابة بأحد البدائل الثلاثة التالية:

$$
\text { لحوافق: تشير إلى مـوقف قبول العبـارة. }
$$

$$
\begin{aligned}
& \text { سعاد إبراهيم يسى، س99 (م، ص VVI. }
\end{aligned}
$$

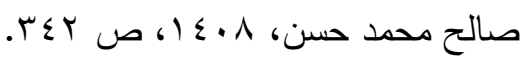


لا أو افق: تشير إلى مـوقف رفض العبارة.

بعد تصهيهم الاستبـانة في صورتها الأولية تم عرضها صلى مسجموعة من الهـحكهين مـن ذوي الخبرة والتخصص في مسجالات البحث العلهي

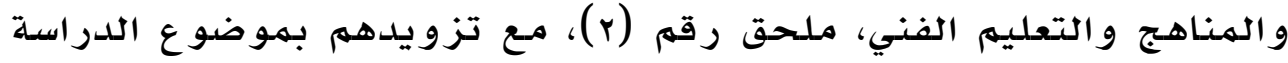
و أهدافها و الطلب منههم دراستها وإبداء رأيهم فيها من حيث المدلول و المهحتوى و مناسبتها لأهداف اللدراسـة والحصول على البيـانات الكلازمـة للبحث و مـلائهتها لشروط الاستبانة و لقد استفادت الباحثة مـن مـلاحظاتهم وإرشاداتهم وقامت الباحثة بناء على ذلك بالحذف والتعديل حسب توجيهاتهم ثم عرضت على الهشرف الذي قام بلدوره ببعض الإرشادات والمهلاحظات التي تم الأخذ بها، وضعت الاستبـانة في صورتها النهائية. وفيما يلي وصف الاستبـانة: اشتملت الاستبـانة على خطاب تقديهم يوضح الغرض من إجراء الدراسـة و يحث المشاركين على التعاون و الاستجابة، كما اشتهلت بجانب ذلك على جزئين رئيسيين الجزء الأول يتضهن للبيانات الأو لية. أمـا الجزء الثاذي فقد اشتهل على (0 محاور) ويحتوي كل مهحور على عدد من العبارات كها هو محددد بالجدول (r-v). جدول (r-v) يوضتح إستراتيجية الاستبانة الموجهة لعينة البحث

\begin{tabular}{|c|c|c|c|}
\hline عدد العبارات & ملى العبارات & عنوان المحور & ترتيب \\
\hline$\Lambda$ & A_l & أسباب ضعف المستوى الدراسي للطلاب المقبولين بالمساق الفني & $i$ \\
\hline 0 & 0.1 & ضعف الميزانية المخصصة للتعليم الفني & ب ب \\
\hline$\checkmark$ & $V_{-1}$ & أسباب تدني نسبة الرضا الوظيفي لمعلمي المساق الفني & ج \\
\hline$r$ & $r_{-1}$ & 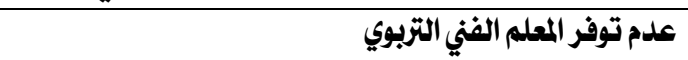 & 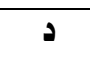 \\
\hline$\wedge$ & A.l & معالجة نسبة تدني الشهادة الفنية بعدد من الوسائل & $\bullet$ \\
\hline
\end{tabular}
صلدق و ثبات الاستبانة

بعد أن قامت الباحثة بكتابـة الاستبـانة في صورتها النهائية تم إجراء دراسـة استطلاعية قبل إجراء الدراسـة الميدانية وذذك لهعرفة درجة الصدق و الثبات الذاتي لهمـا. حيث تهم توزيع استبـانات لعدد حوالي . \% من عدد أفر اد العينـة كها تهـت مـر اعاة توزيع هذه النسـب على أن تشهـل جهيـع 
الوظائف داخل عينـة البحثث.

و بعد جهـع الاستبانات من أفراد كل عينة استطلاعية تم تفريغها وتحليلها لإيجاد ثبات كل استبانة واستخدمت الباحثة طريقة التجزئة النصفيـة حسب معادلة معامل ارتباط بير سون وهي:

$$
\text { معاله الارتباط = }=
$$

و نسبـة لأن معامل الارتباط لا يهثل معامل الثبـات لأن الاستبـانة قسمت إلى جزئين فقد استخدمت الباحثة معادلة للتنبؤ لاسبيرمان - بروان لإيجاد معامل الثبات الكلي وهي: س = $=\frac{ر}{ر+1}$ بالنسبـة للصدق الوصفي للاستبانة فقد اكتفت الباحثة بـآراء الهـحكمين حول صدلاحية الاستبـانة من حيث التصهيم والتنسيق و الصياغة اللغوية ومضدون العبارات وارتباطها بفروض الدراسلة. كها تم إيجاد الصدق الإحصائي لحسـاب الجـذر التربيعي لهعامل الثبـات. بتطبيق هذه الهعادلات على الاستبـانة نجد أن:

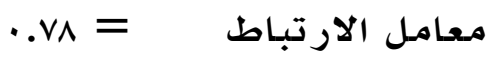

$$
\begin{aligned}
& \text { معامل الثبات الكلي = جیـ. }
\end{aligned}
$$

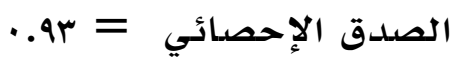

المعالجات الإحصائية: المعات

استخدمت الباحثة عدداً من الهعادلات الإحصائية لهعالجة بيانات الدراسـة الميدانية وقد تم تحليل المعلومات التي جمعت عن طريق الاستبـانة بعد أن تم تنظيهها في جدول مأخوذة من الهحاور الأسـاسية TYE

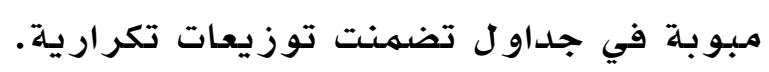


وقد أجرت الباحثة التحليلات الإحصائية مستخدمة:

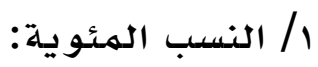

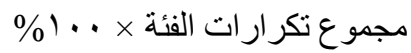

$$
\text { النسب المئوية }
$$

عدد أفراد العينة

r/ معامل ارتباط بيرسون (ر) للتجزئة النصفية وذلك للحصول على

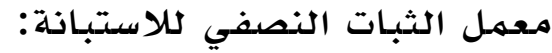
ن مج (س صل) - مج س

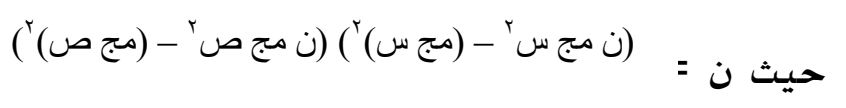

$$
\text { ص = = درجات العبارات الفردية }
$$

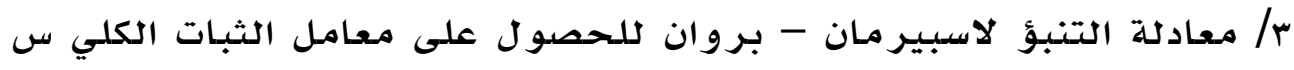

$$
\text { و هي: }
$$

$$
\text { حيث ر معامل الثبات النصفي }
$$

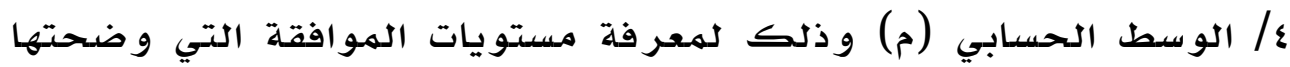

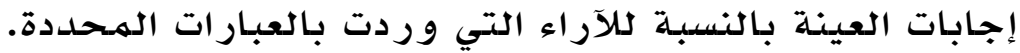

$$
\begin{aligned}
& \text { مج ك س } \\
& \text { ، هي التكر ار } \\
& \text { مج }=
\end{aligned}
$$

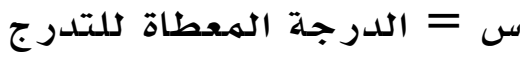

$$
\begin{aligned}
& \text { / الانحر اف المعياري. } \\
& \text { ملخص الفصل الثالث: }
\end{aligned}
$$

تناو لت الباحثة في هذا الفصل إجراءات الدراسـة التي اتبعتها لتتهكن

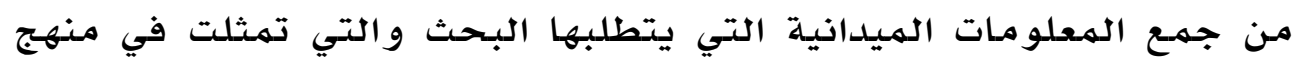

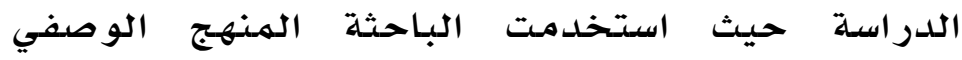


التحليلي. وكانت أدوات الدراسة الاستبانة و الوثائق والهستندات حيث

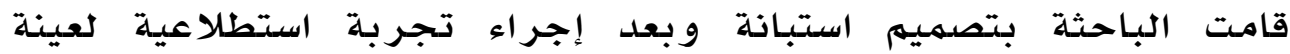

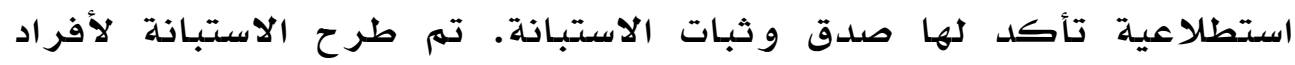
العينة في مواقع عملهم واستخدمت الباحثة بعض الإحصاءات التحليلية كالنسبة المئوية و الوسط الحسابي وذلك لتحليل عبارات الاستبانة

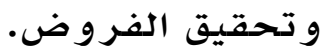




\section{الفصل الرابع \\ تحليل ومناقشة نتائج الدراسة الميدانية}

تمهيد:

في هذا الفصل تناولت الباحثة تحليل ومناقشهة نتائج الدراسـة الهيدانية و التي استخخدمت فيها الاستبـيانات لجمـع الهعلومات وقياس الآراء مححاو لة من خلال عرض ض البيانات وتحليلها التوصل إلى أسبـاب تدذي نسبـة النجاح في الشهادة السودانيـة المساق الفني وكيفيـة معالجـة نسبـة التدني بعدد من الو سـائل.

و اتبعت الباحثة الخطوات التالية: ا- تنـاول نتائج كل مححور مـن مسحاور الاستبـانة على حده.

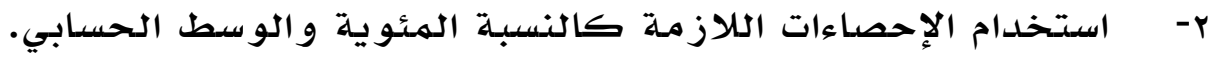
ب- التحليل الإحصدائي الذي يقود إلى الاستتنتاجات. ع- التححقق مـن فروض البـحث.

بعد تفريخ الاستبيانات التي تهم جمعها من عينـة البحث استخدمت

الباحثة في الهعالجة الإحصائية الوسط الحسابي والانحر اف الهعياري. ع - r تحليل استجابات عينة البحث حول عبارات الاستبانة: ع-ץ-1 أ/ من أسباب ضعف المستوى الدراسي للطلاب المقبولين من طلاب التعليم الأكاديمي.

$$
\text { جدو ل رقم (1-1) }
$$

الطلاب المقبولون للتعليم الفني أقل درجة من طلاب التعليم الأكاديمي

\begin{tabular}{|c|c|c|}
\hline النسبة \% & العدد & الإجابة \\
\hline$V \varepsilon .0$ & $r \Lambda$ & أوافق \\
\hline $10 . V$ & $\Lambda$ & لحد ما \\
\hline 9.1 & 0 & لا أوافق \\
\hline$\%$ & 01 & المجموع \\
\hline
\end{tabular}

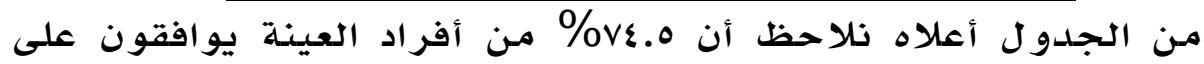
(أن الطلاب المقبولين للتعليهم الفني أقل درجة من طلاب التعليهم الأكاديهي) مـن أسبـاب ضعف الهستوى الدراسي للطلاب الهقبو لين بالهساق الفني بينهما 10.V\% يوافقون ذحد ما و 0.1\% لا يوافقون على ذلك. 


$$
\text { جدول رقم (؟- (r) }
$$

محدودية فرص القبول لطالب التعليم الفني لمواصلة دراسته بالتعليم

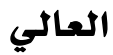

\begin{tabular}{|c|c|c|}
\hline النسبة ٪ & العدد & الإجابة \\
\hline$v \cdot .7$ & rq & أوافق \\
\hline 18.7 & 9 & لحد ما \\
\hline 11.1 & 7 & لا أوافق \\
\hline$\%$ & 01 & المجموع \\
\hline
\end{tabular}

من الجدول أعلاه نلاحظ أن ؟.\%\% من أفراد العينة يوافقون على أن

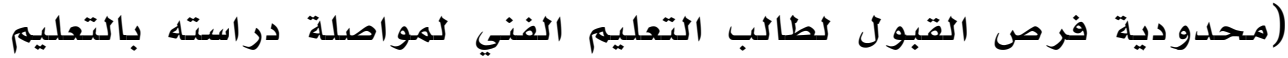

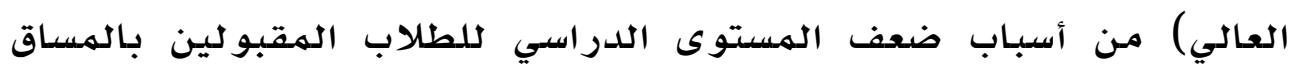

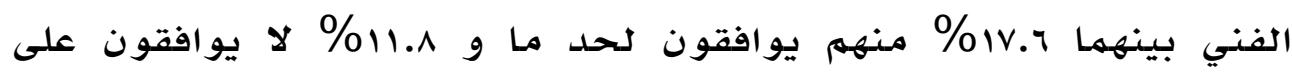

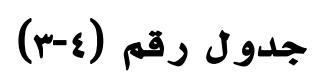

\begin{tabular}{|c|c|c|}
\hline النسبة ؛ & العدد & الإجابة \\
\hline 07.9 & $r q$ & أوافق \\
\hline ro.0 & IT & لحد ما \\
\hline 18.7 & 9 & لا أوافق \\
\hline$\%$ & 01 & المجموع \\
\hline
\end{tabular}

عدم الوضوح والاستقرار في المنهج

من الجدول أعلاه نلاحظ أن 9هو\% من أفراد العينة يوافقون على أن

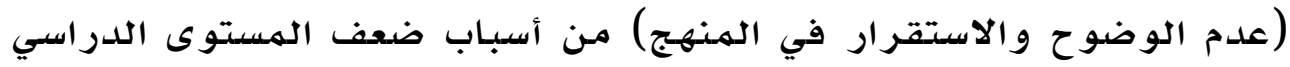

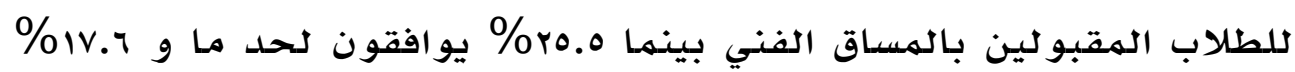
لا يو افقون على ذلك. 


$$
\text { جدول رقم (ع-ع) }
$$

نظرة المجتمع اللدونية ثلتعليم الفني

\begin{tabular}{|c|c|c|}
\hline النسبة ٪ & العدد & الإجابة \\
\hline v7.0 & rq & أوافق \\
\hline r1.7 & 11 & لحد ما \\
\hline$r$ & 1 & لا أوافق \\
\hline$\% 1$. & 01 & المجموع \\
\hline
\end{tabular}

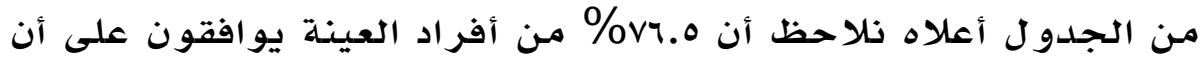

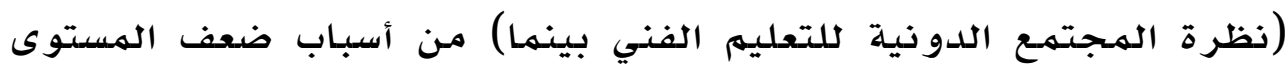

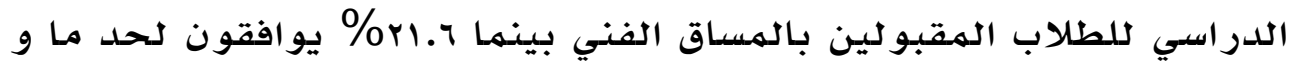
\%r

$$
\text { جدول رقم (ع-0) }
$$

\begin{tabular}{|c|c|c|}
\hline النسبة \% & |العدد & الإجابة \\
\hline ra.E & 10 & أوافق \\
\hline ra.દ & 10 & لحد ما \\
\hline$\varepsilon 1 . Y$ & rI & لا أوافق \\
\hline$\% 1$. & 01 & المجموع \\
\hline
\end{tabular}

ضيق فرص العمل بعد التخرج

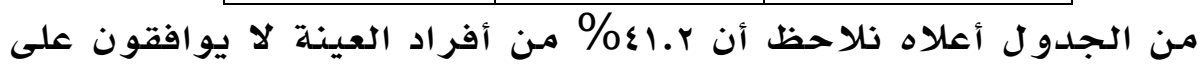

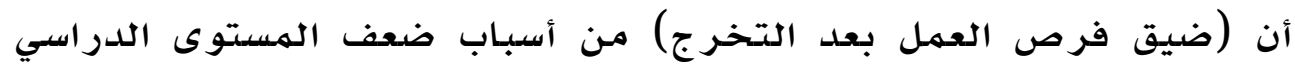

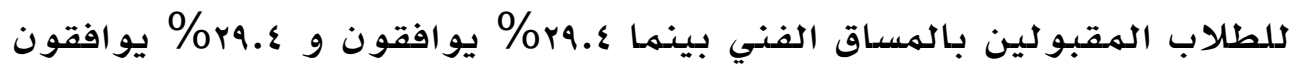

\begin{tabular}{|c|c|c|}
\hline \multicolumn{3}{|c|}{ جدو تدو رقم (ع-7) } \\
\hline النسبة ٪ & العدد & الإجابة \\
\hline$\Lambda \varepsilon . r$ & $\varepsilon r$ & أوافق \\
\hline 11.1 & 7 & لحد ما \\
\hline$r .9$ & $r$ & لا أوافق \\
\hline$\% 1 \cdots$ & 01 & المجموع \\
\hline
\end{tabular}
لحد ما على ذلك.

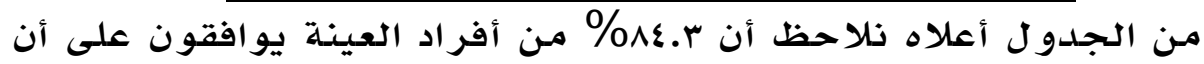

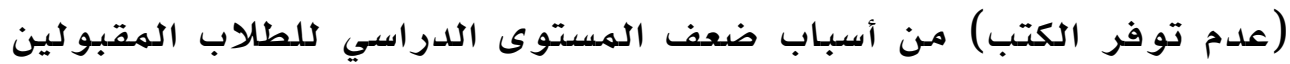


بالمساق الفني بينها ^.11\% يوافقون لحد ما و 9.\% لا يوافقون على ذلك.

$$
\text { جدول رقم (ع-ع) }
$$

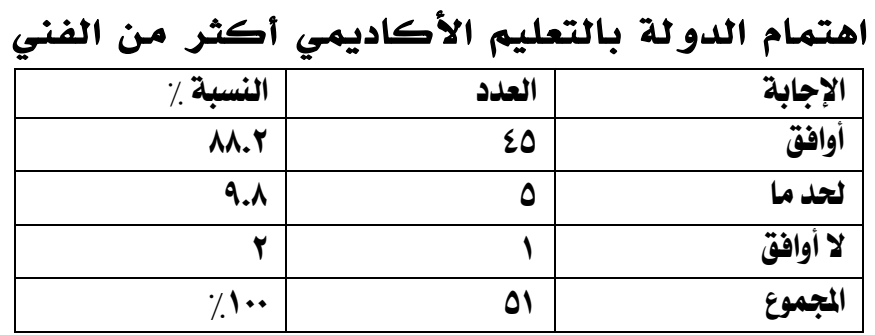

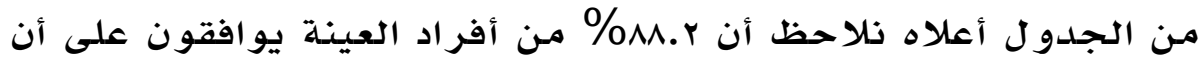

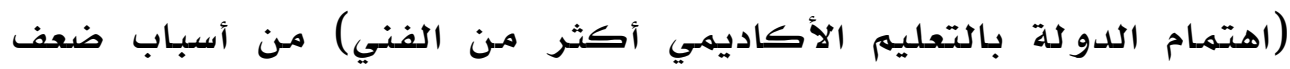

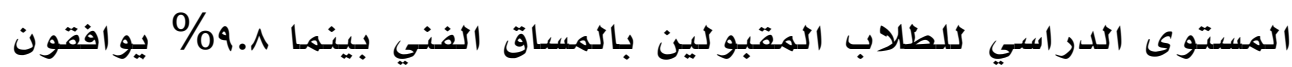

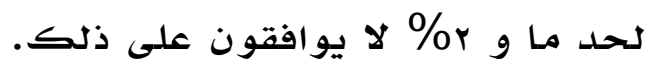

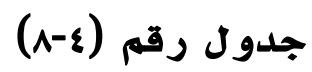

\begin{tabular}{|c|c|c|}
\hline النسبة | & العدد & الإجابة \\
\hline 71.7 & ro & أوافق \\
\hline rl.L & 17 & لحد ما \\
\hline • & • & لا أوافق \\
\hline 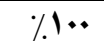 & 01 & المجموع \\
\hline
\end{tabular}

عدم توفر الأجهزة والمعدات وقمات

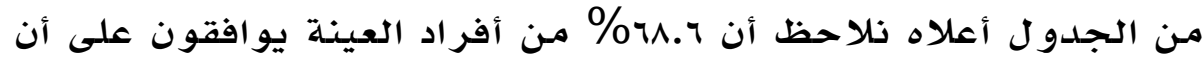

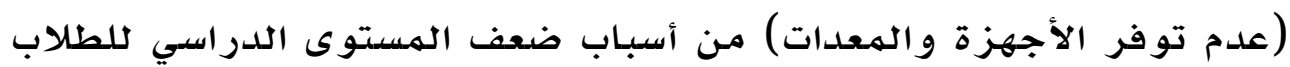

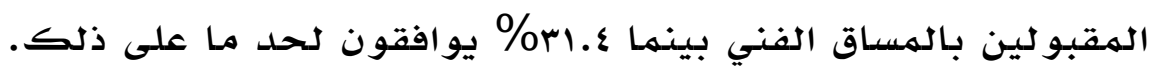

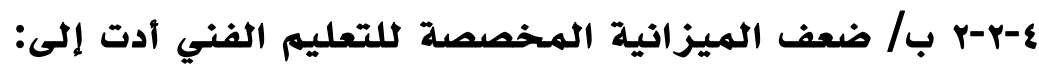

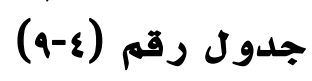

\begin{tabular}{|c|c|c|}
\hline النسبة ٪ & العدد & الإجابة \\
\hline$\Lambda \varepsilon . \Psi$ & $\varepsilon r$ & أوافق \\
\hline IT.V & $v$ & لكد ما \\
\hline$r$ & 1 & لا أوافق \\
\hline$\%$ & 01 & المجموع \\
\hline
\end{tabular}

عدم توفر الأجهزة والمعدات

$7 \Gamma$. 
من الجدول أعلاه نلاحظ أن r.ی^\% من أفراد العينة يوافقون على أن

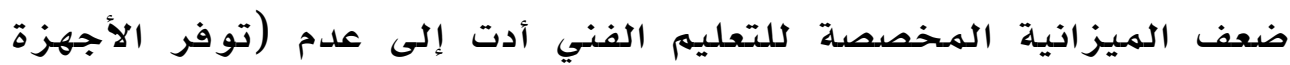

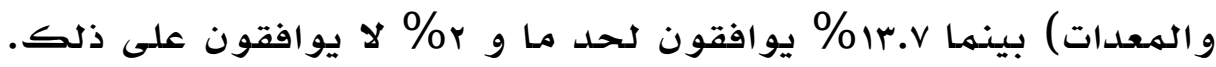

$$
\text { جدول رقم (ع-1.1) }
$$

عدم توفر المعامل المطلوبة ولم

\begin{tabular}{|c|c|c|}
\hline النسبة | & العدد & الإجابة \\
\hline Ar.L & $\varepsilon r$ & أوافق \\
\hline 11.1 & 7 & لحد ما \\
\hline 0.9 & $r$ & لا أوافق \\
\hline$\% 1 \ldots$ & 01 & المججموع \\
\hline
\end{tabular}

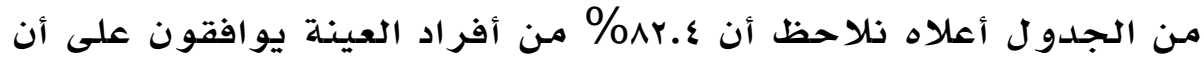

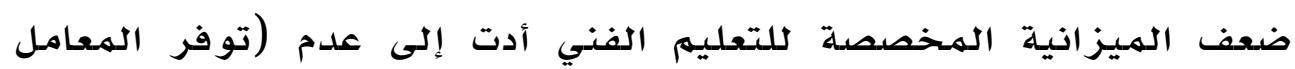

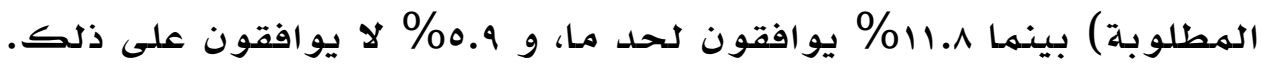

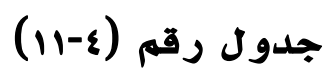

\begin{tabular}{|c|c|c|}
\hline \multicolumn{3}{|c|}{ عدم توفر الورش } \\
\hline النسبة ٪ & العدد - العد & الإجابة \\
\hline$\Delta \varepsilon . q$ & $r \Lambda$ & أوافق \\
\hline rq.r & $r$. & لحد ما \\
\hline 0.9 & $r$ & لا أوافق \\
\hline$\% 1 \cdots$ & 01 & المجموع \\
\hline
\end{tabular}

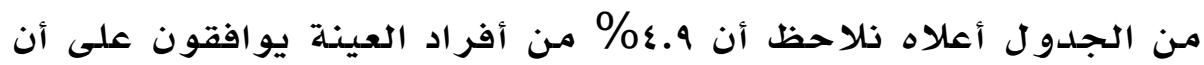

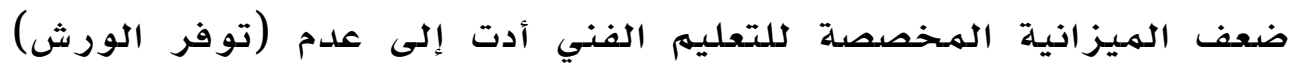

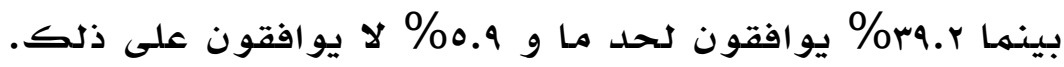

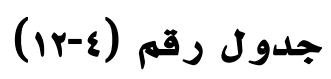

\begin{tabular}{|c|c|c|}
\hline النسبة ٪ & العدد & الإجابة \\
\hline VE.O & rA & أوافق \\
\hline rr.o & ir & لحدد ما \\
\hline$r$ & 1 & لا أوافت \\
\hline$\% 1$. & 01 & المجموع \\
\hline
\end{tabular}

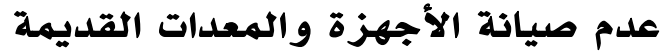


من الجدول أعلاه نلاحظ أن ه.\% م من أفراد العينة يوافقون على أن

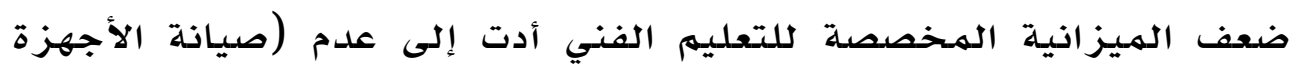

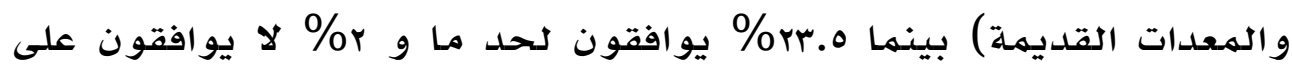
ذلك.

$$
\text { جدول رقم (ع-rا) }
$$

عدم توفر المؤهلين لتشغيل المعدات والأجهزة

\begin{tabular}{|c|c|c|}
\hline النسبة \% & العدد & الإجابة \\
\hline 07.9 & $\mathrm{rq}$ & أوافق \\
\hline Y1.7 & 11 & لحد ما \\
\hline Y1.7 & 11 & لا أوافق \\
\hline$\% 1 \cdots$ & 01 & المجموع \\
\hline
\end{tabular}

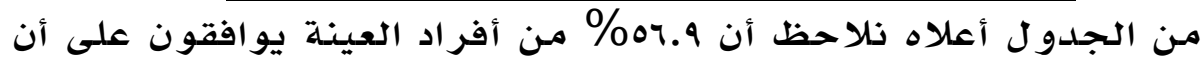

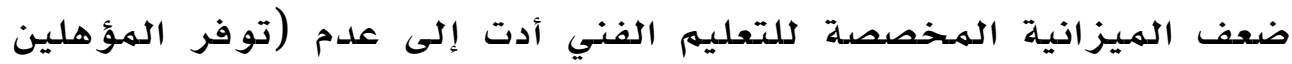

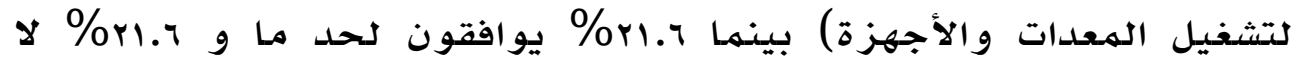
يوافقون على ذلك.

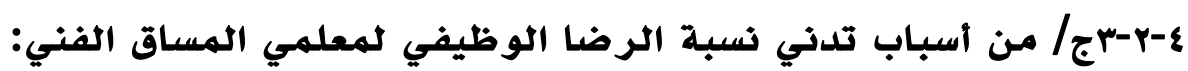

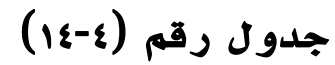

ضعف الفرص في التدريب

\begin{tabular}{|c|c|c|}
\hline النسبة ٪\% & العدد & الإجابة \\
\hline v7.0 & rq & أوافق \\
\hline $10 . V$ & $\wedge$ & لحد ما \\
\hline$V . A$ & $\varepsilon$ & لا أوافق \\
\hline$\%$ & 01 & المجمموع \\
\hline
\end{tabular}

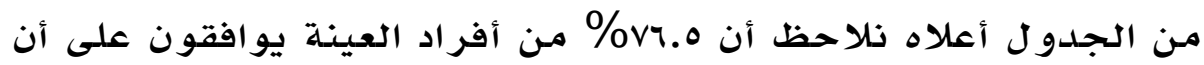

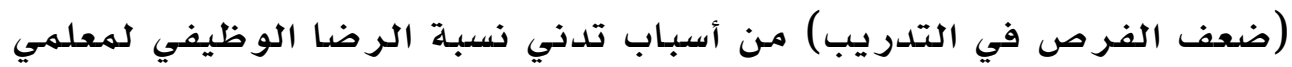

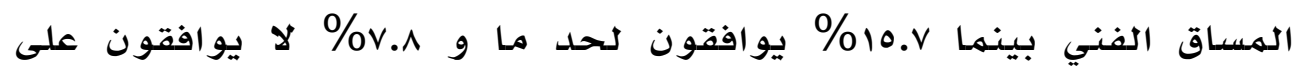
ذلك. 


\begin{tabular}{|c|c|c|}
\hline النسبة ٪\% & العلدد & الإجابة \\
\hline TY.O & $1 \varepsilon$ & أوافق \\
\hline$\sum 9$. . & ro & لحد ما \\
\hline Tr.o & Ir & لا أوافق \\
\hline$\% 1 \cdots$ & 01 & المجموع \\
\hline
\end{tabular}

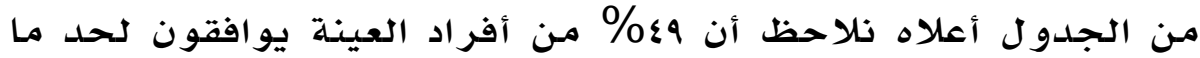

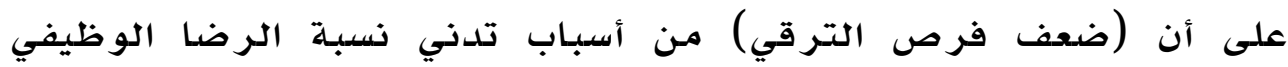

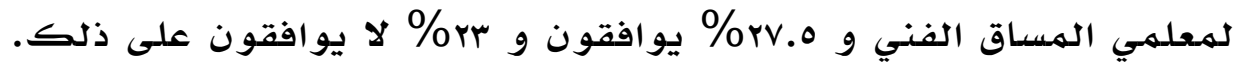

$$
\text { جدول رقم (ع-17) }
$$

ضعف الرواتب والمخحمدات

\begin{tabular}{|c|c|c|}
\hline النسبة ٪ & العدد & الإجابة \\
\hline VA.E & $\varepsilon$. & أوافق \\
\hline IT.V & $v$ & لحد ما \\
\hline V.A & $\varepsilon$ & لا أوافق \\
\hline$\% 1 \cdot \cdot$ & 01 & المجموع \\
\hline
\end{tabular}

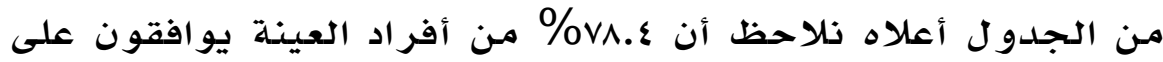

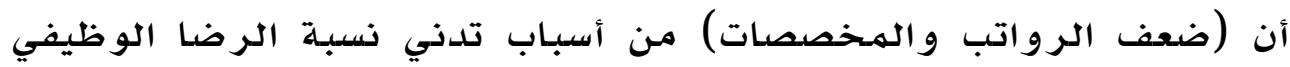

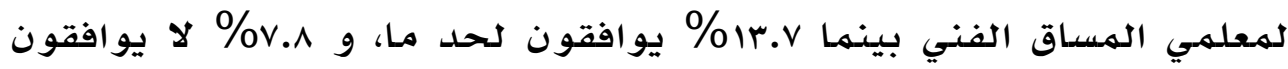
على ذلك.

$$
\text { جدول رقم (iv-ع) }
$$

\begin{tabular}{|c|c|c|}
\hline النسبة \% & العدد & الإجابة \\
\hline rV.r & 19 & أوافق \\
\hline$\varepsilon V .1$ & $r \varepsilon$ & لكد ما \\
\hline $10 . V$ & $\wedge$ & لا أوافق \\
\hline$\%$ & 01 & المجموع \\
\hline
\end{tabular}

عدم وجود فرص للعمل الخاص

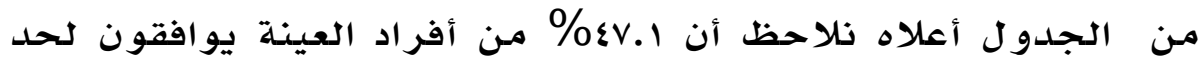

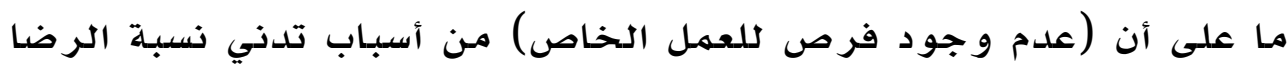

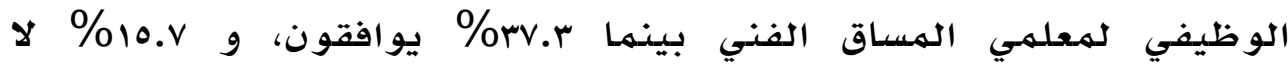


يوافقون على ذلك.

$$
\text { جدول رقم (1N-ع) }
$$

الاهتمام الضعيف من جانب الدو لة بالمعلم الفني

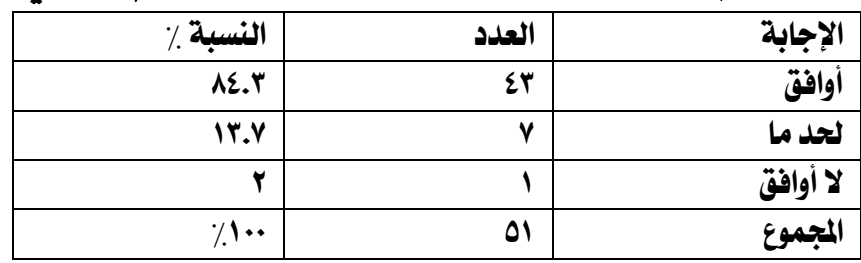

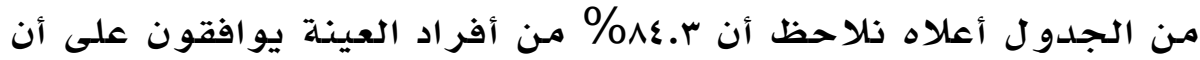

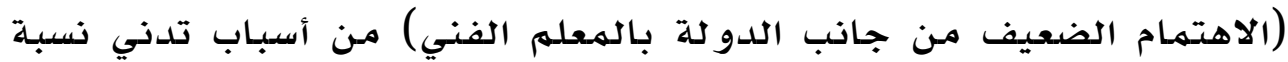

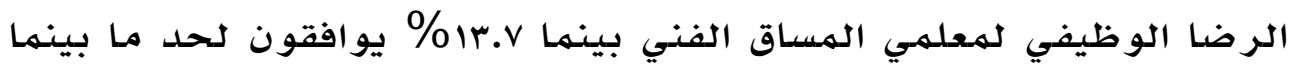

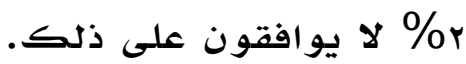

\section{جدول رقم (19-19)}

\section{ضيق فرص الإعارة والانتداب}

\begin{tabular}{|c|c|c|}
\hline النسبة ٪ & العدد & الإجابة \\
\hline 97 & $\sum 9$ & أوافق \\
\hline$r$ & 1 & لحد ما \\
\hline$r$ & 1 & لا أوافق \\
\hline$\%$ & 01 & المجموع \\
\hline
\end{tabular}

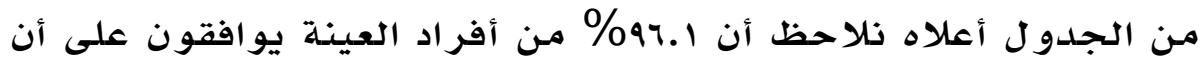

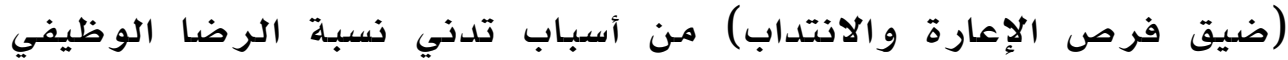

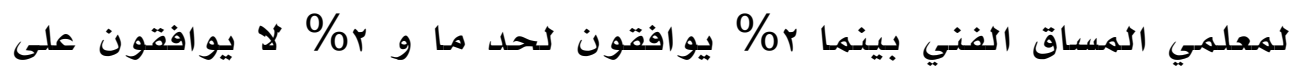

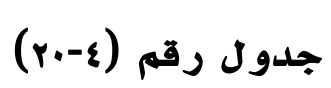$$
\text { ذلك. }
$$

\begin{tabular}{|c|c|c|}
\hline النسبة ٪ & العدد & الإجابة \\
\hline $0 \Lambda . \Lambda$ & $r$. & أوافق \\
\hline rq.દ & 10 & لحد ما \\
\hline 11.1 & 7 & لا أوافق \\
\hline$\%$ & 01 & المجموع \\
\hline
\end{tabular}

ضعف فرص التنافس للوظائف القيادية

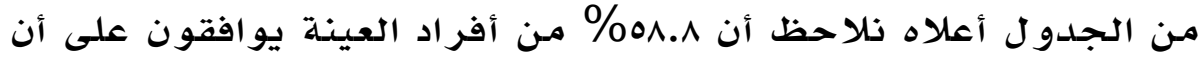


(ضعف فرص التنافس للوظائف القيادية) من أسباب تدني نسبة الرضا

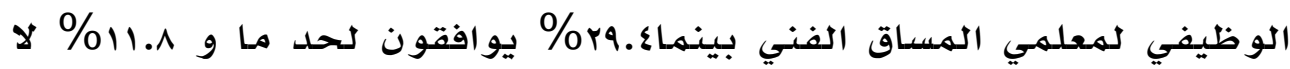
يوافقون على ذلك. ع-ץ-ع د/ من أسباب عدم توفر دلكو المعلم الفني التربوي:

$$
\text { جدول رقم (ع) (rI) }
$$

كليات تلدريب المعلمين للمواد الفنية قليلة جداً

\begin{tabular}{|c|c|c|}
\hline النسبة ٪\% & العدد & الإجابة \\
\hline 71.7 & ro & أوافق \\
\hline $10 . \mathrm{V}$ & $\wedge$ & لحد ما \\
\hline $10 . V$ & $\wedge$ & لا أوافق \\
\hline$\% 1 .$. & 01 & المجموع \\
\hline
\end{tabular}

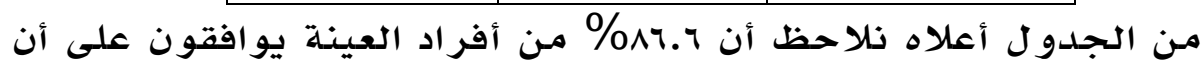

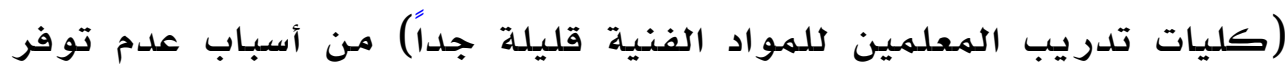

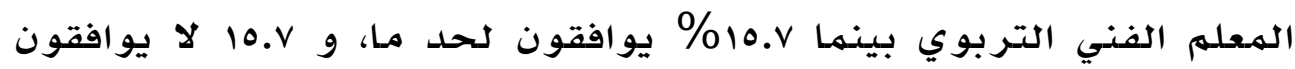
على ذلك.

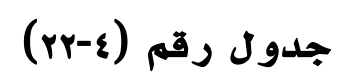

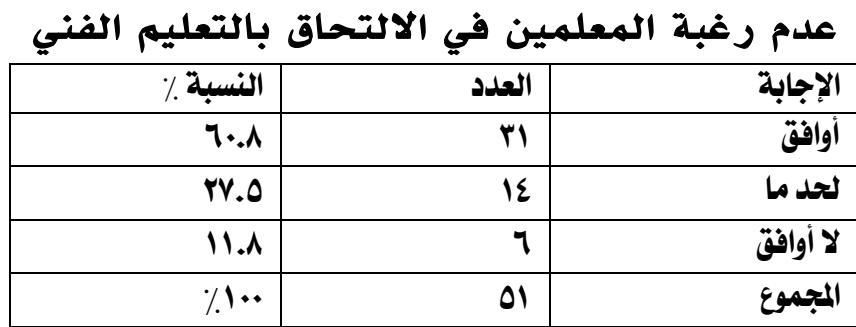

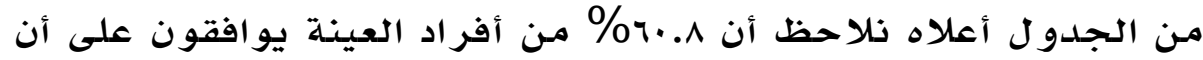

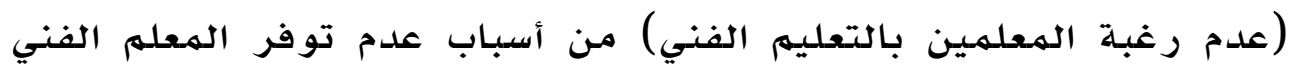

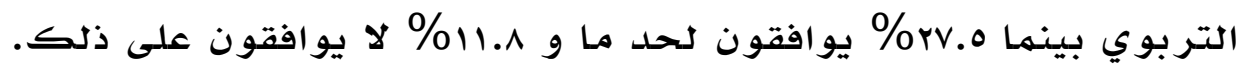

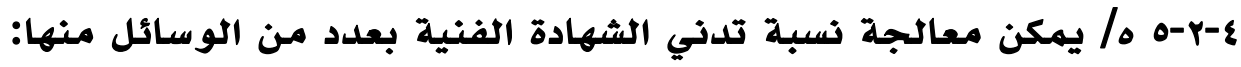




$$
\text { جدول رقم (rr-ع) }
$$

الاهتمام بالتعليم الفني من جانب الدولة وفيم

\begin{tabular}{|c|c|c|}
\hline النسبة ٪ & العدد & الإجابة \\
\hline $1 .$. & 01 & أوافق \\
\hline • & - & لحد ما \\
\hline . & . & لا أوافق \\
\hline$\% 1$. & 01 & المجموع \\
\hline
\end{tabular}

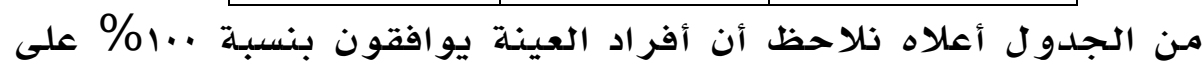

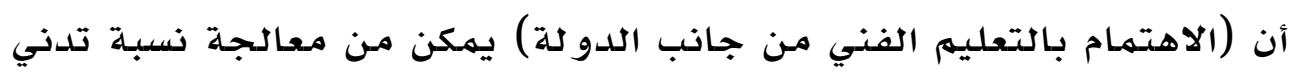
الشهادة الفنية.

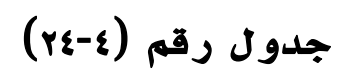

\begin{tabular}{|c|c|c|}
\hline النسبة ٪ & العدد & الإجابة \\
\hline $9 . .5$ & $\varepsilon 7$ & أوافق \\
\hline 9.1 & 0 & لحد ما \\
\hline • & • & لا أوافق \\
\hline$\% 1$. & 01 & المجممع \\
\hline
\end{tabular}

تأهيل المعلمين الفنيين

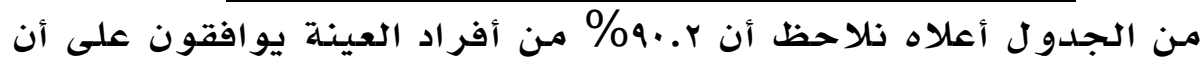

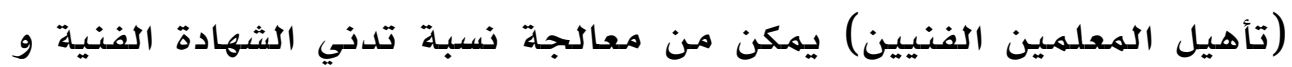

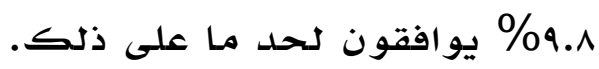

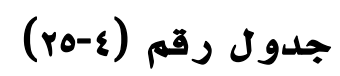

\begin{tabular}{|c|c|c|}
\hline النسبة ٪ & العدد & الإجابة \\
\hline $9 . .5$ & $\varepsilon 7$ & أوافق \\
\hline 9.1 & 0 & لحد ما \\
\hline - & • & لا أوافت \\
\hline$\% 1 \cdots$ & 01 & المجموع \\
\hline
\end{tabular}

التوسع في كليات التربية التي تخرج معلمين للمواد الفنية

من الجدول أعلاه نلاحظ أن r..9\% من أفراد العينـة يوافقون على أن ד 


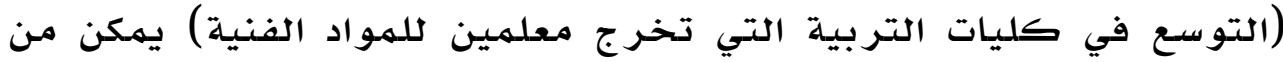

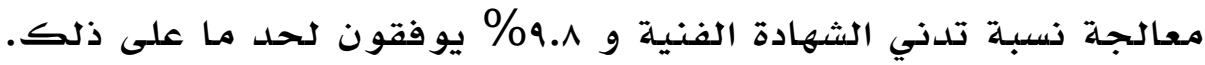

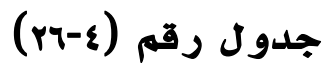

توسيع فرص طلاب التعليم الفني في التنافس للتعليم العالي

\begin{tabular}{|c|c|c|}
\hline النسبة / & العدد & الإجابة \\
\hline MA.Y & ¿0 & أوافق \\
\hline 9.1 & 0 & لحد ما \\
\hline$r$ & 1 & لا أوافق \\
\hline$\% 1$. & 01 & المجموع \\
\hline
\end{tabular}

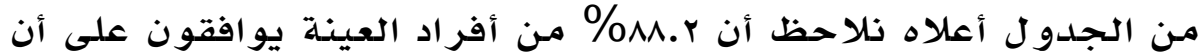

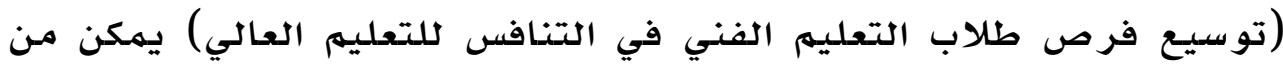

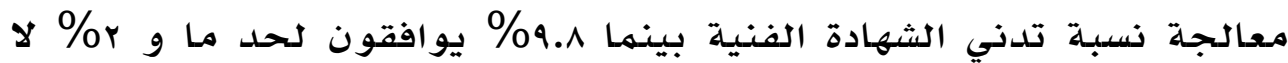
يو افقون على ذلك.

$$
\text { جدول رقم (rv-ع) }
$$

\begin{tabular}{|c|c|c|}
\hline النسبة . & العدد & الإجابة \\
\hline $9 . .5$ & $\sum 7$ & أوافق \\
\hline 9.1 & 0 & لحد ما \\
\hline • & - & لا أوافق \\
\hline$\% 1$. & 01 & المجموع \\
\hline
\end{tabular}

معالجة بيئة العمل بالمدارس

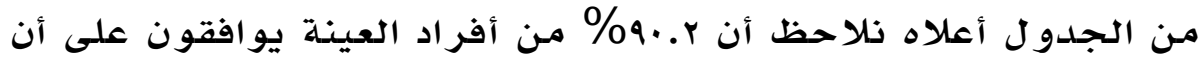

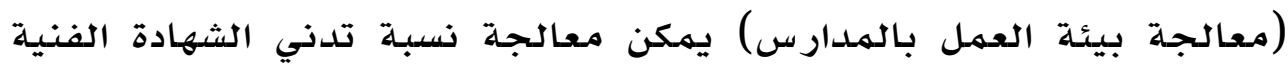

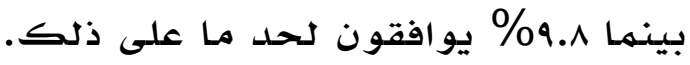

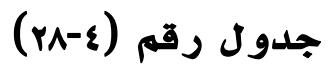

\begin{tabular}{|c|c|c|}
\hline النسبة / & العدد & الإجابة \\
\hline 9r.r & $\varepsilon V$ & أوافق \\
\hline V.A & $\varepsilon$ & لكد ما \\
\hline - & - & لا أوافق \\
\hline$\% 1 \cdots$ & 01 & المجموع \\
\hline
\end{tabular}

توفير الأجهزة والمعدات الكلازمة وعة 


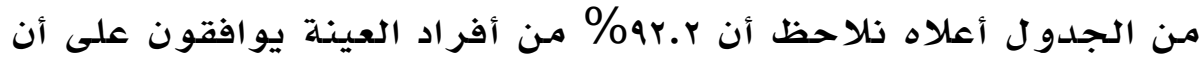

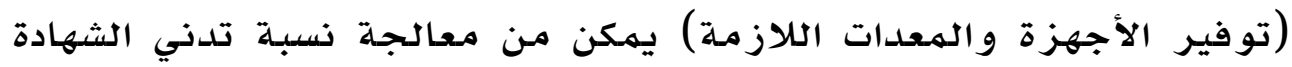

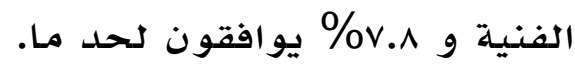

\section{جدول رقم (ra-r)}

تأهيل الورش والمعامل المطلوبة ولم

\begin{tabular}{|c|c|c|}
\hline النسبة . & العدد & الإجابة \\
\hline ar.r & $\sum V$ & أوافق \\
\hline 0.9 & $r$ & لحد ما \\
\hline$r$ & 1 & لا أوافق \\
\hline$\% 1$. & 01 & المجمموع \\
\hline
\end{tabular}

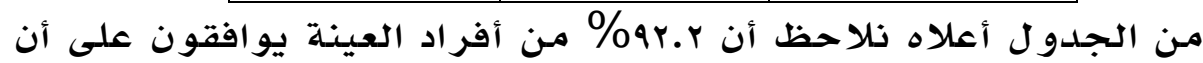

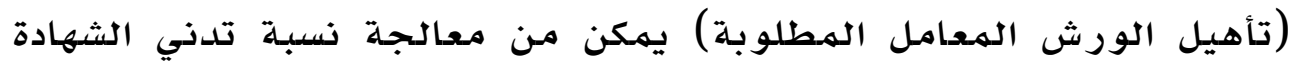

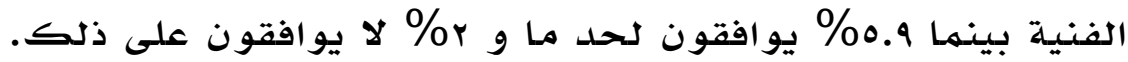

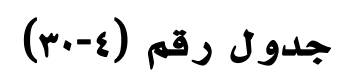

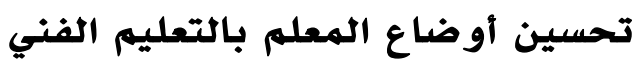

\begin{tabular}{|c|c|c|}
\hline النسبة ٪ & العدد & الإجابة \\
\hline 97.1 & $\varepsilon 9$ & أوافق \\
\hline$r .9$ & $r$ & لحد ما \\
\hline - & . & لا أوافق \\
\hline$\% 1 \cdots$ & 01 & المجموع \\
\hline
\end{tabular}

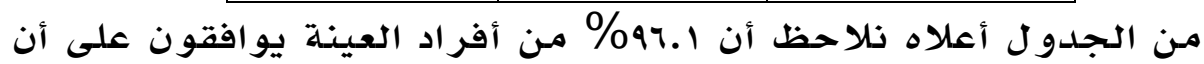

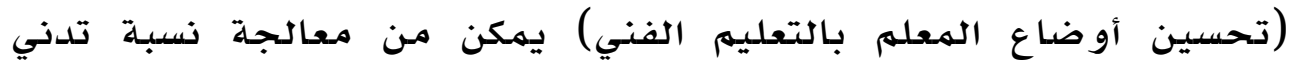

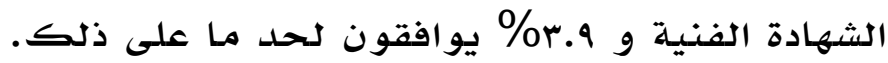




$$
\text { جدول رقم (ع-اب) }
$$

يبين آراء أفراد العينة حول أسباب ضعف المستوى الدراسي للطلاب المقبو لين بالمساق الفني

\begin{tabular}{|c|c|c|c|c|c|}
\hline \multirow{2}{*}{ 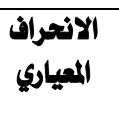 } & \multirow{2}{*}{ العابي } & \multicolumn{3}{|c|}{ درجة الموافق2 } & \multirow[t]{2}{*}{ 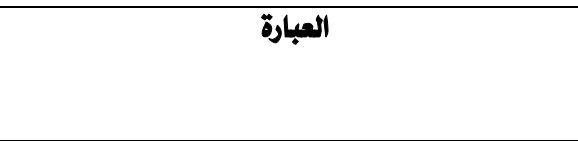 } \\
\hline & & 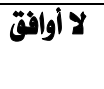 & العدما القة & أوافق & \\
\hline .77 & T.7 & 0 & $\wedge$ & rı & التعليم الأكاديمي القبولين للتعليم الفني أقل درجة من طلاب \\
\hline$\cdot \%$. & r.T & 7 & 9 & ri & دراسته بالتعليم العالي القبول لطالب التعليم الفني لمواصلة \\
\hline$\therefore \mathrm{rA}$ & T.E & 9 & ir & rq & ب/ عدم الوضوح والاستقرار في المنهج \\
\hline$\cdot . \Sigma A$ & r.V & 1 & 11 & $r 9$ & ع/ نظرة المجتمع الدونية للتعليم الفني \\
\hline$\cdot . \wedge \varepsilon$ & $r$ & M & 10 & 10 & 10 ضيق فرص العمل بعد التخرج \\
\hline .0 & T.A & $r$ & 7 & $\psi \varepsilon$ & 17/ عدم توفر الكتب \\
\hline.$\varepsilon$ & r.9 & 1 & 0 & ¿o & V/ اهتمام الدولة بالتعليم الأكاديمي أكثر من الفني \\
\hline .0 & T.V & . & 17 & ro & 1/ عدم توفر الأجهزة والمعدات \\
\hline
\end{tabular}

تناو لت الباحثة في هذا الفصل نتائج كل ملفحل محور من مـحاور الاستبانة التي

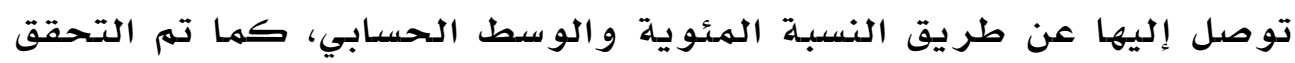
من أسئلة البحث. 


\section{خاتمة البحث}

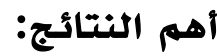

توصلت الباحثة لمهموعة الته من النتائج هي:

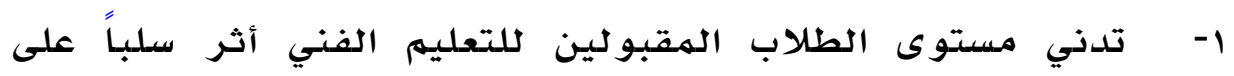

$$
\text { المستوى الدر اسي لهمه. }
$$

r- من أسباب تدني المستوى الدر اسي لطلاب التعليم الفني محلدودية

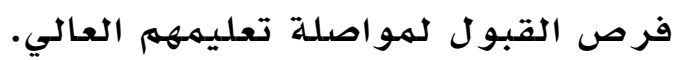

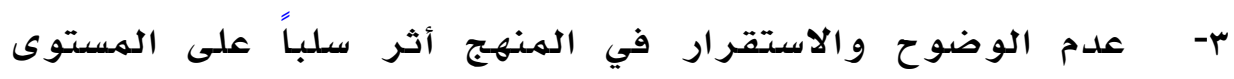

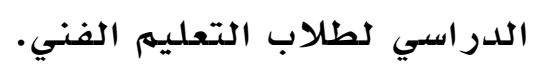

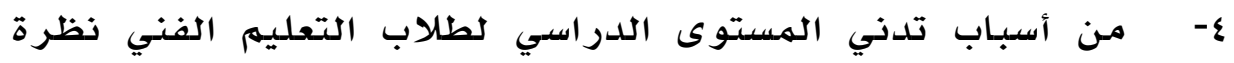
المجتهمع الدونية للتعليم الفني.

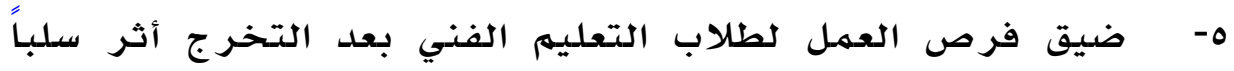

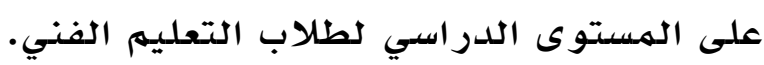

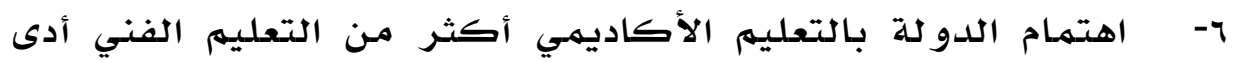

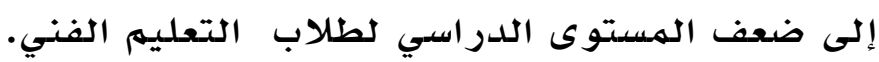

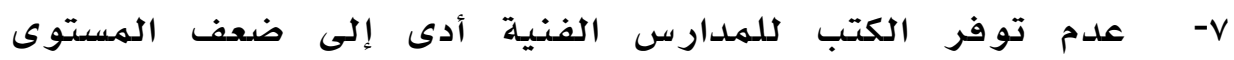
الدراسي لطلاب التعليم الفني.

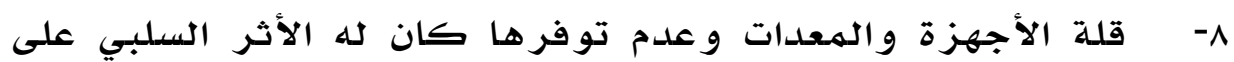

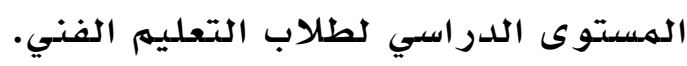

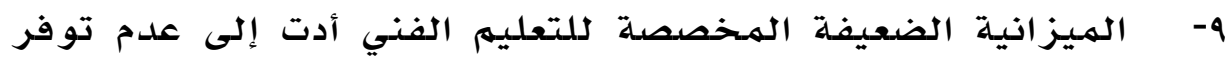

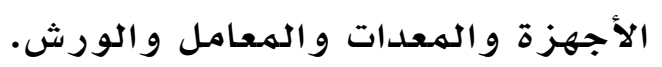

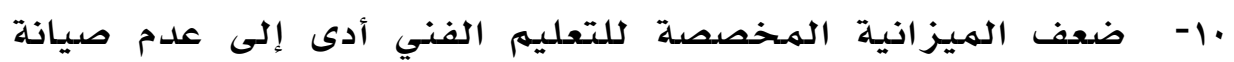
الأجهزة و المعدات.

11- من أسباب عدم الرضا الوظيفي لمعلمي المساق الفني، ضيق فر ص الترقي و التدريب.

rا- ضعف الرواتب والمخصصات أدى إلى وائلى عدم الرضا الوظيفي لمعلهي المسـاق الفني. rا- مـن أسباب عدم الرضا الوظيفي لمعلهي المساق الفني ضيق فرص $7 \varepsilon$. 
الإعارة و الانتداب.

عا- من أسباب عدم توفر الهعلم الفني التربوي قلة كليات التربية الفنيـة.

10- عدم رغبـة الهعلمين بالالتحاق بالتعليهم الفني أدى إلى عدم توفر الهعلم التربوي الفني.

17- اهتهام الدو لة بالتعليهم الفني يساعد في تحسين نسبة النجاح للشهادة السودانية الهسـاق الفني.

IV - التوسع في كليات التربية الفنية يسـاعد في تحسين نسبـة النساح لطلاب الشهادة السوداني الهساق الفني. 11- توسيع فرص طلاب التعليم الفني في التنافس للتعليم العالي يؤدي إلى تحسين المستوى الدر اسي لههم. 19- توفير الأجهزة والمعدات اللازية ميساعد في تحسين المستوى الدراسي لطلاب التعليهم الفني. •r- تحسين أوضاع الهعلهم بالتعليهم الفني يسـاعد في تحسين نسبة

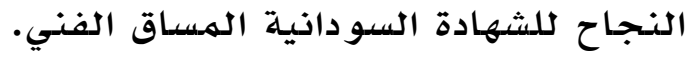

التو هسيات:

على ضوء النتائج السابقة توصي الباحثة بالآتي: ا- إنشاء مدارس نهوذجية فنيـة في كل و لاية من ولايات السودان الهـختلفة لتحسين نسبـة النجاح في الشهادة الفنية.

r- رفع الهـيزانية الهـخصصدة للتعليهم الفني من قبل الدو للة. ب- زيادة عدد كليات التربية الفنيـة لتأهيل المعلهم الفني التربوي. ع- إحكام الربط بين التعليهم الفني الثانوي والتعليهم التقني العالي بحيث يتكاملان و ظيفة و مضهمونا وبحيث تكون الدراسة في المستوى العام أسـاسـاً ومؤهلاً للدر اسـة في المستوى العالي. ه- عند التخطيط للهمدارس الفنية يوضع في الاعتبار الهتطلبات الأسـاسية التي تمكنها من أداء وظيفتها بالصدورة المطلوبـة من

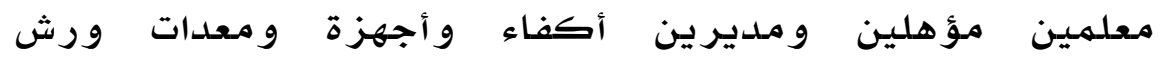


ج- إدخال مزيد من التخصصات الجديدة في التعليه الفني تلبي

احتياجات التطور المستهر وظهور الدهر الههن الجديدة.

- V وضع شروط خلمـة مجزية للمعلمين الفنيين حتى يتهم استقطاب

واستمر ار المعلهم الكفء للعمل في مجال العهل التعليم الفني.

^- العهل على توفير البيئة المدلرسية الصالحهة.

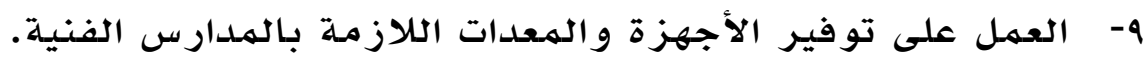

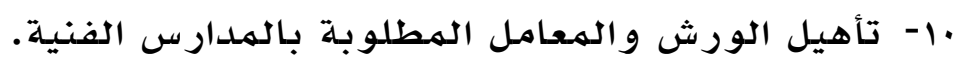

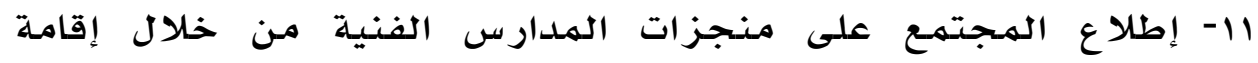

المعار ض و إجر اء المسابقات للهمهار ات الإنتاجية.

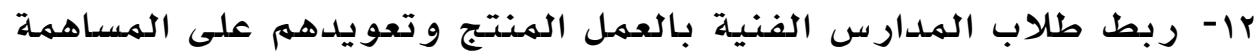

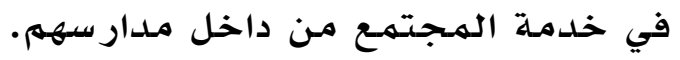




\section{قائمة بأسمائ المراجع العربية}

\section{مراجع البحث:}

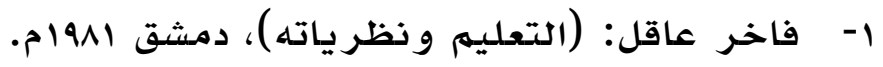

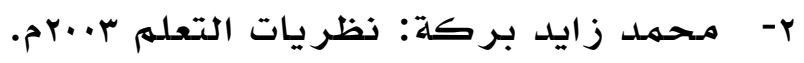

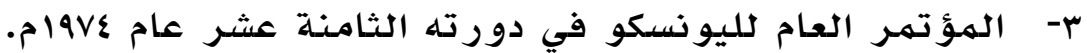

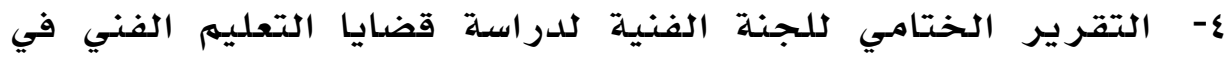

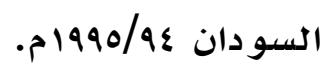

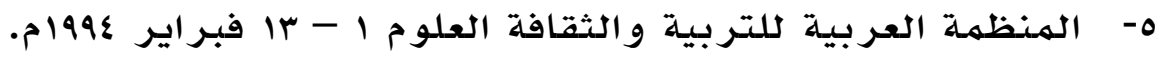

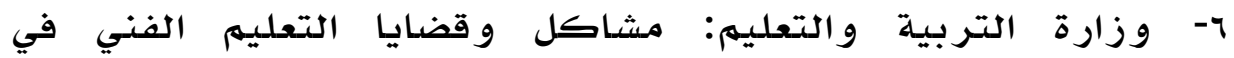

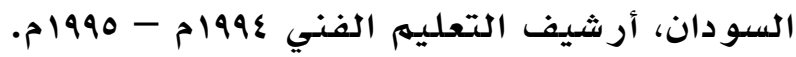

- - هاشهم محمد سعيد عبدالوهاب: السياسات العامة للتعليم الفني،

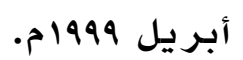

^- وزارة التربية والتعليه: حاضر ومستقبل التعليم في السودان،

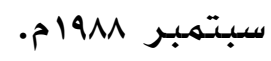

9- محمد حسن شلبي: تقويهم وتطوير التعليهم الفني، وزارة التربية

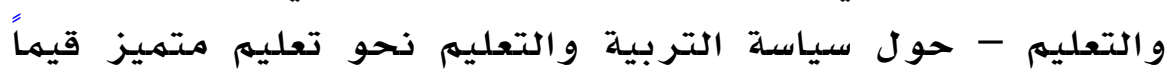

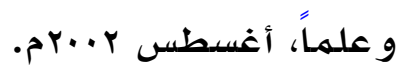

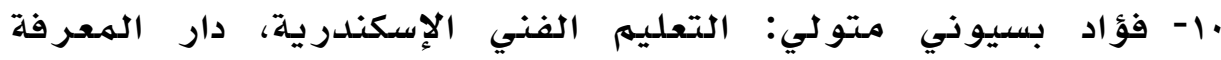

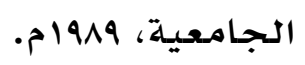

11- ميشيل ايف برنار: المعاهد الجامعية للتكنو لوجيا، ترجمة: أحمد الجدائ

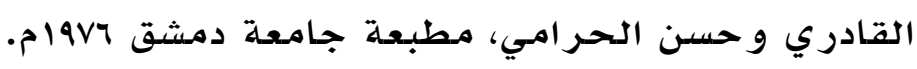




\section{ملحق (1)}

الاستبانة بصورتها النهائية

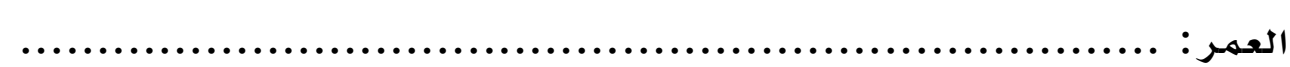

الوظيفة: الدرجة:

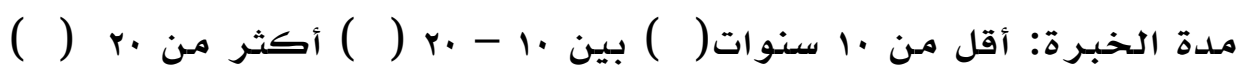

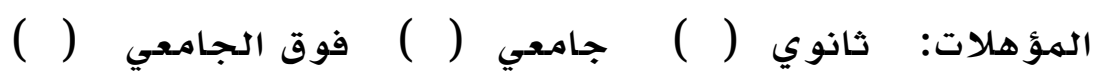
الجزء الثاني: عبارات الاستبانة:

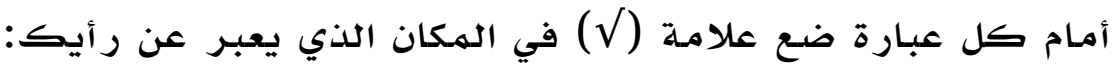
أ/ من أسباب ضعف المستوى الدراسي للطلاب المقبولين بالمساق الفني:

\begin{tabular}{|c|c|c|c|}
\hline لا أوافق & لكد ما & أوافق & المقبولون \\
\hline & & & 1/ الطلاب المقبولين للتعليم الفني أقل درجة من طلاب التعليم الأكاديمي \\
\hline & & & ب/ محدودية فرص القبول لطالب التعليم الفني لمواصلة دراسته بالتعليم العالي \\
\hline & & & "/ علدم الوضوح والاستقرار في المنهج \\
\hline & & & ع/ نظرة المجتمع الدونية للتعليم الفني \\
\hline & & & 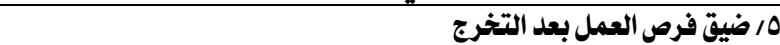 \\
\hline & & & 17/ عدم توفر الكتب \\
\hline & & & N/ اهتمام الدولة بالتعليم الأكاديمي أكثر من الفني \\
\hline & & & 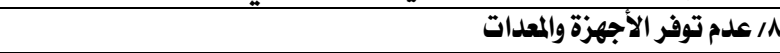 \\
\hline
\end{tabular}

ب/ ضعف الميزانية المخصصة للتعليم الفني أدت إلى عدم:

\begin{tabular}{|c|c|c|c|}
\hline لا لأوافق & 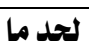 & أوافق & \\
\hline & & & 1/ توفر الأجهزة والمعدات. \\
\hline & & & آب/ توفر المعامل المطلوبة \\
\hline & & & ب/ توفر الورش \\
\hline & & & ع/ صيانة الأجهزة والمعدات القديمة \\
\hline & & & ه / توفر المؤهليز لتشغيل المعدات والأجهزة \\
\hline
\end{tabular}

ج/ من أسباب تدني نسبة الرضا الوظيفي لمعلمي المساق الفني:

\begin{tabular}{|c|c|c|c|}
\hline لا لا أوافق & 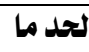 & أوافت & \\
\hline & & & | ر ضعف الفرص في التدريب \\
\hline & & & ب/ ضعف الفرص في الترقي \\
\hline & & & ז/ ضعف الرواتب والمخصصات \\
\hline & & & ع/ عدم وجود فرص للعمل الخاص \\
\hline
\end{tabular}


0 / الاهتمام الضصيف من جاذب الدولة بالمعلم الفني 7/ ضيق فرص الإعارة والانتداب

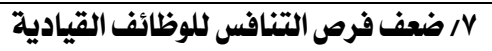

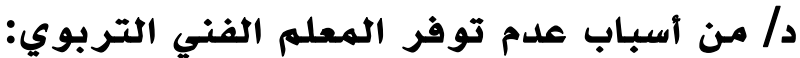

\begin{tabular}{|c|c|c|c|}
\hline لا أوافق & 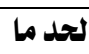 & أوافق & \\
\hline & & & ا / كليات تدريب المعلمين للمواد الفنية قليلة جداً \\
\hline & & & r/ عدم رغبة المعلمين في الالتحاق بالتعليم الفني \\
\hline
\end{tabular}

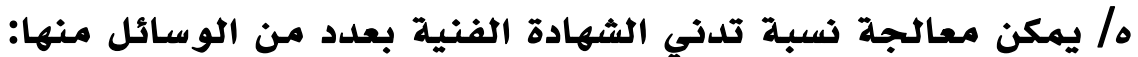

\begin{tabular}{|c|c|c|c|}
\hline لا أوافق & 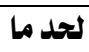 & أوافق & \\
\hline & & & / / الاهتمام بالتعليم الفني من جانب الدولة \\
\hline & & & r/ تأهيل المعلمين الفنيين \\
\hline & & & ب/ التوسع في كليات التربية التي تخرج معلمين للمواد الفنية \\
\hline & & & ع/ توسيع فرص طلاب التعليم الفني في التنافس للتعليم العالي \\
\hline & & & 0/ معالجة بيئة العمل بالمدارس \\
\hline & & & 1/7 توفير الأجهزة والمعدات اللازمة \\
\hline & & & V N تأهيل الورش والمعامل المطلوبة \\
\hline & & & 1/ ـ تحسين أوضاع المعلم بالتعليم الفني \\
\hline
\end{tabular}

ملحق رقم (r)

حلو ل يو ضيح ححم المشكلة بإحصائيات من الشهادة السوداثية المساق الفني

\begin{tabular}{|c|c|c|c|c|c|c|c|c|c|c|c|c|c|c|}
\hline \multicolumn{2}{|c|}{$r . .1$} & \multicolumn{2}{|c|}{$r \ldots$} & \multicolumn{2}{|c|}{1999} & \multicolumn{2}{|c|}{1994} & \multicolumn{2}{|c|}{ 1994 } & \multicolumn{2}{|c|}{1997} & \multicolumn{2}{|c|}{1990} & \\
\hline .9. & 步 & .7. & 占 & 3 & 占. & .7. & 齿 & .7. & 占 & .9. & 齿 & .7. & 齿 & \\
\hline$\% \Delta 0$ & $1 . r \varepsilon r$ & \%.हT.Y & AMII & $\%$ \%A.9 & $\Lambda .7 \Lambda$. & $\% r V .9$ & 97Tr & \%ЕA.r & llar. & $\% \varepsilon 7.7$ & $11 v \cdot 1$ & $\%$ ¿A. . & 11.71 & طيون \\
\hline ناجعون & & ثاجحوذ & & ناجحون & & ناجحون & & ناجحون & & ناجحون & & ناجحون & & \\
\hline \%У乏.r & & $\% 77.0$ & & $\% 70.1$ & & $\% 97$ & & $\% 77.9$ & & $\% 17$ & & $\%$ \%T.E & & أكاديميوذ \\
\hline
\end{tabular}

